\title{
Creating a Community-Based Protocol to Prevent Unintended Pregnancy in Homeless Women in Monongalia County, West Virginia
}

Jessica Eva Wukasch

West Virginia University, jew0032@mix.wvu.edu

Follow this and additional works at: https://researchrepository.wvu.edu/etd

Part of the Community Health Commons, Community Health and Preventive Medicine Commons, Other Mental and Social Health Commons, Public Health and Community Nursing Commons, Public Health Education and Promotion Commons, and the Women's Health Commons

\section{Recommended Citation}

Wukasch, Jessica Eva, "Creating a Community-Based Protocol to Prevent Unintended Pregnancy in Homeless Women in Monongalia County, West Virginia" (2020). Graduate Theses, Dissertations, and Problem Reports. 7698.

https://researchrepository.wvu.edu/etd/7698

This Problem/Project Report is protected by copyright and/or related rights. It has been brought to you by the The Research Repository @WVU with permission from the rights-holder(s). You are free to use this Problem/Project Report in any way that is permitted by the copyright and related rights legislation that applies to your use. For other uses you must obtain permission from the rights-holder(s) directly, unless additional rights are indicated by a Creative Commons license in the record and/ or on the work itself. This Problem/Project Report has been accepted for inclusion in WVU Graduate Theses, Dissertations, and Problem Reports collection by an authorized administrator of The Research Repository @ WVU. For more information, please contact researchrepository@mail.wvu.edu. 
Creating a Community-Based Protocol to Prevent Unintended Pregnancy in Homeless Women in Monongalia County, West Virginia

Jessica Eva Wukasch, MSN, APRN, FNP-C

\begin{abstract}
Doctor of Nursing Practice Project submitted to the School of Nursing at West Virginia University

in partial fulfillment of the requirement for the degree of

Doctor of Nursing Practice
\end{abstract}

Roger Carpenter, Ph.D., Chair

Toni Dichiacchio, D.N.P.

Amanda Newhouse, M.S.W

Department of Nursing

Morgantown, West Virginia

2020

Keywords: homeless women, unintended pregnancy, community-based interventions, protocol, pregnancy prevention

Copyright 2020 Jessica Eva Wukasch 


\begin{abstract}
Creating a Community-Based Protocol to Prevent Unintended Pregnancy in Homeless Women in Monongalia County, West Virginia

Jessica Eva Wukasch, MSN, NP-C
\end{abstract}

Background: At any given time, 10\% of homeless women are pregnant, about twice the rate of all U.S. women of reproductive age (5\%) (Healthcare for the Homeless, 2001). According to Healthcare for the Homeless Council ([HHC], 2012), approximately " $73 \%$ of pregnancies among homeless women were unintended at the time of conception." In addition, "about $12 \%$ of homeless children are placed in foster care compared to $1 \%$ of other children" (HHC, 2012). There is an evident need to address unintended pregnancy among homeless women.

Objective: The overall objective was to create an accessible and useful community-based protocol to reduce the rate of unintended pregnancy in homeless women in Monongalia County, West Virginia.

Methods: This project followed a quality improvement PDSA cycle (Plan, Do, Study, Act). It was completed in four phases: 1) phone interviews with homeless women, 2) focus group with community stakeholders, 3) protocol creation based on feedback from stakeholders and homeless women, and 4) survey completed by focus group participants evaluating acceptability and usefulness of the protocol.

Results: Themes from interviews with women included timely and convenient access to safety, hygiene, transportation and help, housing, and views on pregnancy and contraception. Themes from focus group served as the organizing structure for the created protocol. Focus group participants surveys indicated an acceptability rating of 4.3-4.6, with 5 being strongly agree. Responses regarding usefulness of the protocol were 3.8-4.4, with 5 being strongly agree. Survey responses also recognized a need to include missing stakeholders and need for greater collaboration with other stakeholders.

Discussion: The framework (PDSA cycle) was an effective way to create this protocol. The experiences described in the interviews with homeless women and during the focus group were reflective of the literature and the challenges associated with caring for this vulnerable population. Focus group participants, inclusion of missing stakeholders and community partnerships are vital to the sustainability of this project. 


\section{Dedication}

This project is dedicated to the homeless women who inspired the genesis of this project. Their strength in facing adversity moved me personally and professionally. My hope is the results of this project will give homeless women in Monongalia County (and beyond) a voice that is heard and will develop a community of care to meet their unique needs. 


\section{Acknowledgements}

Only by the grace and sustaining power of Jesus Christ was this project completed. "He is before all things, and in Him all things hold together" (Colossians 1:17). He has encouraged, strengthened and supported me through this endeavor. My hope is this project will bring Him glory and help more people love the marginalized in our world unconditionally as Christ does.

My strong, faithful, loving husband, Jesse, who regularly sacrificed his time and energy to help me complete this goal. His encouragement and belief in my ability to accomplish a task provided the strength I needed on many weary nights. He is my greatest earthly gift.

Our daughter, Lily, you are a joy and a light in this dark world. Lily, I pray you will one day stand up for the vulnerable and speak words of life to women who are less fortunate.

My Johnson and Wukasch family. Thank you for listening, providing endless words of encouragement and being there for our little family during this busy time. I could not have completed this journey without you.

My chair, Dr. Roger Carpenter, was essential in guiding me through this project. His time, insight, and investment made this project better in every way. Thank you also to my committee members, Dr. Toni Dichiacchio and Amanda Newhouse for their unique perspective and example in advocating for the underserved.

Thank you to the focus group members whose valuable insight and time made this project sound and sustainable for future use and development.

Finally, Milan Puskar Health Right, who took a chance on this nurse practitioner. Their compassionate approach to loving others, including the homeless and often forgotten, was an inspiration to me. The patients, staff and providers were a vital part of this project's foundation. 


\section{Table of Contents}

$\begin{array}{ll}\text { Dedication } & \text { iii }\end{array}$

Acknowledgements $\quad$ iv

Table of Contents $\quad \mathrm{V}$

Introduction $\quad 1$

$\begin{array}{ll}\text { Background } & 2\end{array}$

$\begin{array}{ll}\text { Literature Review and Synthesis } & 4\end{array}$

$\begin{array}{ll}\text { Theoretical Framework } & 6\end{array}$

$\begin{array}{lr}\text { Qualitative Approach } & 8\end{array}$

Project

Design of Evidence-Based Project 9

$\begin{array}{ll}\text { Feasibility } & 11\end{array}$

Project Impact Analysis $\quad 13$

$\begin{array}{ll}\text { Resources } & 14\end{array}$

Congruence of Organization's Strategic Plan to Project 14

Evidence of Key Site Support 15

$\begin{array}{ll}\text { Measurable Project Objectives } & 15\end{array}$

$\begin{array}{ll}\text { Results } & 16\end{array}$

$\begin{array}{ll}\text { Discussion } & 23\end{array}$

$\begin{array}{ll}\text { Recommendations } & 26\end{array}$

$\begin{array}{ll}\text { Conclusion } & 28\end{array}$

$\begin{array}{ll}\text { Attainment of DNP Essentials } & 29\end{array}$

$\begin{array}{ll}\text { References } & 31\end{array}$ 


\section{Index of Appendices}

Appendix A Criteria for Homeless Women Being Interviewed 35

Appendix B Journalistic Phone Interview Questions for Homeless Women 36

$\begin{array}{lll}\text { Appendix C } \quad \text { List of Community Stakeholders } & 37\end{array}$

Appendix D Focus Group Discussion Question 38

$\begin{array}{lll}\text { Appendix E } & \text { Protocol } & 40\end{array}$

$\begin{array}{lll}\text { Appendix F } & \text { Resource List } & 45\end{array}$

Appendix G Evaluation of the Acceptability of the Development and Usefulness of the Protocol 55

$\begin{array}{lll}\text { Appendix H } & \text { Budget Plan } & 57\end{array}$

Appendix I Measurable Project Objectives Evaluation Plan 58

Appendix J Phone Interviews with Homeless Women in Morgantown 60 
Creating a Community-Based Protocol to Prevent Unintended Pregnancy in Homeless Women in Monongalia County, West Virginia

\section{Introduction}

This project was inspired by several homeless women encountered at the free clinic where the project lead (DNP student) served as a nurse practitioner in Morgantown, West Virginia. The initial inspiration was a homeless woman who presented with upper respiratory symptoms who was taking several psychiatric medications. Knowing she was of childbearing age and these medications were teratogenic, she was asked if she was using contraception and her answer was "no". Ironically, when asked if she wanted contraception her answer was "yes". The plan was for her to get a Depo-Provera injection temporarily until she could have an intrauterine device (IUD) placed at the local health department. Since she had Medicaid, she was required to pick up the Depo-Provera at a local pharmacy and bring it back to the clinic for administration. These steps never happened and two months later she returned pregnant with her sixth child. A greater misfortune was she was unable to house her child and her child was placed in state custody along with her previous five children. It is uncertain if she is currently on contraception.

This is one of many heartbreaking stories not unfamiliar to women in the homeless communities across this country. There are numerous known and unknown barriers to preventing unplanned pregnancy in this vulnerable population. Through this project, these women have an opportunity to reflect on and share obstacles they face or have faced through being homeless and their experiences with pregnancy and pregnancy prevention. The information collected from interviews with homeless women will be infused into a focus group with community stakeholders who serve homeless women. The focus group will allow community stakeholders to 
discuss practical methods for addressing this issue at a community level. The insights from the women and the specific ideas for addressing this problem that arise from the focus group of stakeholders will be used as the data for creating a community-based protocol with a goal of reducing the rate of unintended pregnancy in homeless women in Monongalia County, West Virginia.

\section{Background}

Unintended pregnancy can be a difficult, emotion-filled experience for any woman but even more so for a homeless woman who is struggling to survive. According to the Healthcare for the Homeless Clinicians" Network (2012), at any given time "10\% of homeless women are pregnant, about twice the rate (5\%) of all U.S. women of reproductive age." A study done by Gelberg et al. (2008) found about " $73 \%$ of pregnancies among homeless women were unintended at the time of conception." For a homeless woman, this contributes another significant physical and emotional challenge to their ever-present daily struggles to find safety, food, and shelter. Fortunately, pregnancy also represents a rare strategic opportunity for services to connect with especially vulnerable individuals at a moment when they yearn to change their lives (Smid et al., 2010). Because pregnancy in homeless women is more common and often unintended, further research is needed to establish more effective prevention measures specifically for this population.

For the purposes of this project, homelessness is defined by the U.S. Department of Health and Human Services as, "an individual who lacks a fixed, regular, and adequate nighttime residence" (National Healthcare for the Homeless Council, 2019). In addition, unplanned or unintended pregnancy is defined by the Center for Disease Control and Prevention (2015) as a pregnancy that is "unwanted (no children were desired) or mistimed (pregnancy occurs earlier 
than desired)." Furthermore, unintended pregnancy typically results from one of the following: not using contraception, or inconsistent or incorrect use of effective contraceptive methods (CDC, 2015).

Unintended pregnancy in homeless women also affects the subsequent children. Healthcare for the Homeless (2001) found " $12 \%$ of homeless children are placed in foster care compared to $1 \%$ of other children.” Healthcare for the Homeless (2001) points out how this experience can have a cyclical effect. Approximately $70 \%$ of mothers who were placed in foster care while they were children will have at least one of their children end up in foster care (Healthcare for the Homeless, 2001). Experiences of homelessness in early childhood are associated with adverse outcomes, such as hunger, socio-emotional and other developmental delays, and poor academic achievement (Forum on Child and Family Statistic, 2018). Another important factor to consider in unintended pregnancy is the cost. In 2010, according to the Guttmacher Institute (2014), the federal and state governments spent approximately \$145 million on unintended pregnancies in West Virginia alone.

These statistics clearly indicate a need to address unintended pregnancy in homeless women which impacts our economy and the quality of life for the women and their children. This project is an opportunity to learn from these women and community stakeholders' experiences with unintended pregnancy in homeless women in Monongalia County. With their insights and the insights of stakeholders in the community, this project will promote the needs of these women and create a realistic and accessible protocol for the community to utilize to address those needs. Ultimately, this project seeks to lay the groundwork to reduce the cost of unintended pregnancy, decrease the number of homeless children who may enter into the foster 
care system, and set these women up for the best health and social outcomes despite unavoidable challenges.

\section{Literature Review and Synthesis}

Despite the varied yet significant personal, social and financial repercussions of unintended pregnancy in homeless women, there are very few studies focusing on this population and methods for improving outcomes. This is likely due to the transient nature of homeless populations. One study by Gelberg et al. (2008) looked at some of the reasons unintended pregnancies happen more often in homeless women. The study found that health is not a priority for homeless women, transportation and scheduling can be burdensome, and that being homeless leads some to feel stigmatized by health care providers (Gelberg et al., 2008). According to National Coalition for the Homeless (2009), domestic and sexual violence is the leading cause of homelessness for women and families, and " $20-50 \%$ of all homeless women and children become homeless as a direct result of fleeing domestic violence". Homeless women are far more likely to experience violence of all sorts compared with women who are not homeless because of a lack of personal security when living outdoors or in shelters (National Coalition for the Homeless, 2009). Lack of affordable housing and long waiting lists for assisted housing mean that many women are forced to choose between abuse and the streets.

Many homeless women resort to using ineffective methods of contraception. In a study by Corey et al. (2017), “94\% of the homeless women they surveyed did not want to get pregnant but $59 \%$ relied on condoms and $27 \%$ on withdrawal." In addition, $67 \%$ of these women said they were never counseled or given the opportunity to have a long-acting reversible contraceptive (LARC) such as an IUD or implant (Corey et al., 2017). Saver et al. (2012), through National Health Care for the Homeless Practice-Based Network, found although homeless women were 
found to have access to contraceptive services, they usually were only provided methods with high user-based failure rates.

A study done by Kennedy et al. (2014) points out multiple barriers to using contraception and to accessing reproductive health care services among homeless women. Barriers included inability to prioritize health due to competing demands, shelter-related obstacles, provider practices that impede access to reproductive health care services, and change in the power dynamics while homeless, making women more vulnerable to sexual exploitation (Kennedy et al., 2014). The American College of Obstetricians and Gynecologists ([ACOG], 2016) points out additional factors that contribute to homeless women being unable to obtain needed health care. These factors include the lack of health insurance, the inability to purchase or acquire medications, the lack of knowledge of where and when to obtain health care, long wait times at medical facilities, and the lack of transportation to and from medical facilities (ACOG, 2016). Kennedy et al. (2014) recommends several methods to overcome barriers including providing contraceptive services at the homeless shelters, secure lockers for storing contraceptives, sameday STI testing and IUD insertion, in addition to offering services that may facilitate housing or protect them from intimate partner coercion or violence.

According to the ACOG (2016), lack of access to health care is a profound issue for the homeless population, with $73 \%$ of homeless individuals reporting at least one unmet health need. Because homeless women feel ignored, stigmatized or disrespected by the health care system, many homeless women admit that they often live without essential resources even though this may compromise their health, they do not use the health care system unless it is an emergency (ACOG, 2016). As a result, they have higher rates of poor health status, mental illness, poor birth outcomes, and mortality. The Substance Abuse and Mental Health Service Administration 
(2011) estimates that $30 \%$ of individuals who are chronically homeless have mental health conditions and approximately 50\% have substance use problems as well. Mental illness, substance abuse, domestic violence, and being too sick to seek care create additional obstacles in obtaining needed services. Homeless individuals may not seek care because of denial of health problems and fear of losing their children if found to be homeless (ACOG, 2016).

Education for all women is an important part of contraceptive choice and effective use. An unexpected outcome of a study done by Gelberg et al. (2008) found being partnered, being monogamous, and not engaging in sex trade all predicted nonuse or rare use of contraception. Therefore, homeless women in a monogamous relationship deserve the same, if not more, education about contraception if pregnancy prevention is what they desire. This study also found education about contraceptive methods, encouragement to use contraception, and having a regular source of care may play an important role in reducing unintended pregnancies among homeless women (Gelberg et al., 2008). Anderson et al. (2019) did a study comparing the standardized CDC poster for contraception and a more patient-center poster to educate women on effectiveness of contraception. This study found that both posters could reduce unplanned pregnancy, but the more patient-centered poster increased contraceptive knowledge and the likelihood of a woman choosing a more effective method (Anderson et al., 2019). These findings indicate a need for an approach that is compassionate, patient-centered, educational, and community-based to effectively prevent unintended pregnancy in homeless women.

\section{Theoretical Framework}

An appropriate theoretical framework for this project was Discovery Interviews. According to the National Health Service (2009), the Discovery Interview process is “a framework to improve the match between the services professionals provide and the needs of the 
people who depend on them" (p. 7). This framework provides an opportunity for the homeless women who were interviewed to have a voice pertaining to their experiences with unintended pregnancy and contraception specifically within the community where they reside. At the same time, community stakeholders discussed their experiences and challenges with serving homeless women. By listening to those involved in receiving and providing care, there can be a better understanding of the needs of homeless women and how to improve or adapt community services.

Within the context of Discovery Interviews, the goal is to generate continuous quality improvement by using incremental change models like PDSA (Plan, Do, Study, Act) cycles to generate rapid feedback and reduce risk (NHS, 2009). These quality improvement cycles are directly inspired by listening to the stories of patients and those who serve/care for them. According to the NHS (2009), barriers to change are often reduced when many different people are involved in trying something out on a small scale before implementation. Using the PDSA method of implementation aims to add benefit to patient and care providers while not incurring additional risk.

The project leader chose to follow a journalistic approach for the interviews with homeless women using guidance from the 2018 Requirement on Scholarly and Journalistic Activities from the Office of Human Research Protections (Department of Health and Human Services [HHS], 2018). This allowed the women to provide information about their general experience and perspective but did not elicit personal or confidential information. After providing an IRB-approved cover letter to the women, the interviews were conducted over the phone with a journalistic approach to allow for generalized responses to their experiences with homelessness, pregnancy and resources in the community. 
Results of the interviews were then synthesized, and themes assessed. In the Discovery Interview framework, it is important to categorize levels of change (i.e. small and obvious with immediate implementation, more attention, and problems that require additional investigation) (National Health Service, 2009). Finally, once establishing a plan for change it was essential to seek feedback from community stakeholders on the feasibility of a proposed practice change. The Discovery Interview process, even while using a journalistic approach, requires an appropriate mindset focused on identifying needs through listening. Therefore, solutions are not built before the issues are assessed. The issues discussed during the interviews with homeless women were reviewed with the community stakeholders who created the protocol and determined the effectiveness of the plan for change not the project leader.

\section{Qualitative Approach}

In addition to qualitative interviews with the women, focus groups are an effective method for gaining input from community stakeholders. "Focus group discussion is frequently used as a qualitative approach to gain an in-depth understanding of social issues" (O.Nyumba et al., 2018). According to O.Nyumba et al. (2018) focus groups aim to obtain data from a purposely selected group of individuals rather than from a statistically representative sample. For this study, community stakeholders who interact directly or indirectly with homeless women affected by unintended pregnancy in Monongalia County were gathered in a private room at the WVU School of Nursing (via Zoom or in-person) to discuss a plan for cooperative prevention of unintended pregnancy in homeless women.

The community stakeholders in Monongalia County are listed in Appendix B. Stakeholders from Monongalia County attended a scheduled focus group where they discussed their current practice, struggles, victories and ideas for enacting positive change to prevent 
unintended pregnancy in homeless women in their community (see Appendix $\mathrm{C}$ for focus group discussion questions). These questions were generated by the project leader (DNP student) and her committee who are familiar with focus groups and qualitative research. The process included the following steps: brainstorming to generate a list of questions relevant to preventing unplanned pregnancy in homeless women; highlighting critical questions from the list and arranging the order of questions from general to specific. The focus group included a facilitator (project lead) and three recorders (committee members/faculty).

\section{Project}

\section{Design of Evidence-Based Project}

This community-based quality improvement project is aimed at a long-term goal of reducing unintended pregnancy in homeless women in Monongalia County, West Virginia. Though this project will not assess that particular outcome, its intent is to create a communitybased protocol to effectively address this need. This project was founded on seeking out homeless women in the community who are willing to discuss their experiences with homelessness and unintended pregnancy while in Monongalia County. The protocol was developed from the input of the homeless women and specifically from what was discussed during the focus group with stakeholders in the Monongalia County community. As a metric, the feasibility of the protocol was assessed by the different community stakeholders who serve homeless women in Monongalia County and contributed to the focus group.

This project was completed in four phases.

\section{Phase 1: Interviews with Homeless Women}

1. A letter of support was completed by the director of the agency where the homeless women were interviewed (Milan Puskar Health Right). 
2. Specific staff members at the agency identified 3-4 homeless women who meet the criteria (See Appendix A for criteria) to be interviewed and were willing to participate.

3. The project was explained, and a cover letter were given to the women who agree to participate in a phone interview with the project leader (DNP student) lasting up to 30 minutes. Anonymity was emphasized by the use of private phone rather than in-person interviews.

4. The interview was a journalistic interview with no identifying information released/requested (see Appendix B for homeless women interview questions). Notes were taken during the interview; nothing was audio recorded. The objective of this activity was to provide an accurate and evidence-based portrayal of the individuals involved, and not to develop generalizable knowledge (HHS, 2018). The focus was on their view of the current system and methods they believe would be better to help homeless women avoid unintended pregnancy.

\section{Phase 2: Focus Group with Community Stakeholders}

1. Community stakeholders were identified by the project leader (DNP student) with assistance from her faculty advisor and Assistant Dean for Community Engagement at the WVU School of Nursing (see Appendix C for list of stakeholders).

2. Each stakeholder was contacted directly to gain support and request participation in a focus group.

3. With letter of support from the stakeholders, they attended an in-person or remotely accessed (Zoom) focus group at the WVU School of Nursing on June 24, 2020. 
4. There were standardized questions to begin discussion. There was NO specific patient information discussed; general themes derived from Phase I were discussed. The focus group lasted two hours (see Appendix D for focus group questions).

5. In attendance, were three recorders and the project leader (DNP student).

\section{Phase 3: Create Protocol}

1. The project leader (DNP student) analyzed all information from the focus group(s) with community stakeholders.

2. The data from the focus group was organized into categories to provides a stepwise approach to addressing the needs of homeless women in the community in order to prevent unplanned pregnancy. The protocol is focused and easy to review (see Appendix $\mathrm{E}$ and $\mathrm{F}$ for protocol and resource list).

3. The protocol was shared with project committee to assess for accuracy.

\section{Phase 4: Evaluation of Protocol}

1. Once protocol was complete and evaluated with the committee, it was sent to stakeholders to edit and evaluate it for usefulness and acceptability via Qualtrics survey (see Appendix G for survey questions). They were given one weeks to return edits and complete the survey evaluation regarding feasibility of the protocol.

2. Edits from stakeholders were applied to the protocol (if relevant). A final version of the protocol will be made available to stakeholders after successful project completion.

\section{Feasibility}

In order for this project to be feasible, it was essential to provide privacy and a safe, comfortable environment for the homeless women who were willing to share their perspective. The interviews with the women were completed on a private phone line while they were at Milan 
Puskar Health Right. They were given a cover letter explaining the project with verbal consent completed prior to interview. Data collection was on a computer that has a password lock and notes were recorded on paper without any identifiers.

The phone interviews with the women were completed prior to the declaration of a pandemic from the virus COVID-19. The focus group was scheduled for approximately one month after the university essentially closed due to the pandemic, so it was immediately postponed indefinitely with the possibility of virtual meeting. Another date was rescheduled over two months after the initial date due to social distancing that was mandated throughout the entire country. This put the focus group at risk for decreasing interest in the project and lack of participation due to concerns of the virus. The pandemic also affected in-person participation versus virtual participation which could have inevitably affected the dynamics of the group.

In order for the focus group to continue and remain effective it was essential to stay in communication with the community stakeholder and discuss forthcoming plans for another meeting date. The initial goal was to have a focus group with stakeholders in person or, if necessary, selective individuals could attend remotely. The date of the group was moved several months to improve the chances of meeting in-person. Several surveys were sent out to decide on the best date and time for each participant. It was necessary to also assess whether participants were willing to meeting via visual/audio platform if in-person was not possible. Another important aspect of having a focus group of busy stakeholders was to give them an accurate expectation of the time for the group and additional time needed for protocol evaluation. Respecting the time of the stakeholders was essential to maintaining their interest and support.

Sustainability of this project will be based on the conciseness, simplicity and adaptability of the protocol. It will need to be comprehensive, concise and useful to many different types of 
community stakeholders who serve homeless women. For most community service providers, it will be important to connect with their leaders and front-line staff to decide what methods of distributing information from the protocol will be most effective. The protocol will be disseminated in an electronic format for ease of accessibility, sharing and editing. Once again, making necessary edits from the evaluation (Qualtrics survey) completed by the focus group participants after the protocol is created with ongoing evaluation and editing is imperative for effective implementation.

\section{Project Impact Analysis}

This project has potential for several areas of impact. First, it can reduce the number and cost of unplanned pregnancies in homeless women in Monongalia County, West Virginia. As a result, there will be fewer children who are homeless and inevitably enter the foster care system due to lack of safe and proper housing. The increased utilization of educational materials and brief yet impactful interventions established by this protocol will help increase the use of effective contraceptive methods in homeless women. These goals are more long-term and will not be measured by this project and may also take some time and additional resources to be achieved.

The long-term impact potential of this project is the creation of a network of care for homeless women in the Monongalia County community. The network will be able to identify and support homeless women by giving convenient, effective and timely help and resources including effective contraception. Also, this protocol seeks to support the people and organizations who care for homeless women by reducing the cost and burden associated with unplanned pregnancy in this vulnerable population. 


\section{Resources}

The budget for this project is attached in Appendix H. There was no outside funding for this project or any incentives for the participants. If interested, the homeless women were given a hygiene kit supplied by Health Right after the interview was completed. The project leader (DNP student) donated a box of combs and brushes for the clinic to assist in this effort.

\section{Congruence of Organization's Strategic Plan}

The challenges surrounding homelessness are not unfamiliar to leaders in the city of Morgantown, WV. In 2013, the Morgantown City Council developed a Homeless and Addiction Strategy by developing a Community-Wide Plan to Reduce Homelessness. In 2019, panhandling and concerns of local businesses about the growing homeless population created a need to revisit the issues of homelessness and addiction in the city. In October 2019, the city held a special work session to discuss homelessness and addiction and invited community stakeholders to discuss methods to address it. This discussion led to the development of a workplan presented late November 2019 to the Morgantown City Council (Brake, 2019).

The primary goal of this workplan was to "identify a process to formulate solutions for the growing problems related to homelessness, drug and alcohol addiction and other related issues" (Brake, 2019). In order to address these issues, they have identified the importance of "consistency across area jurisdictions, to communicate with residents, business owners and all stakeholders" (Brake, 2019). Their framework aligns with the focus of this project to listen to stakeholders and to develop a plan to create consistency and communication across agencies to help more homeless individuals. The pillars of the Morgantown City Council approach to homelessness and addiction include community engagement, current assessment of numbers and needs, coordinated response and sustainable solutions. 
In terms of unintended pregnancy prevention, as an organization ACOG (2016) recognizes homeless women represent a vulnerable population requiring special attention. Homeless women are at higher risk of injury and illness and are less likely to obtain needed health care than women who are not homeless indicating a need for attention and action (ACOG, 2016). According to their Committee Opinion, "it is essential to undertake efforts to prevent homelessness, to expand community-based services for the homeless, and to provide adequate health care for this underserved population" (ACOG, 2016). Health care providers can help address the needs of homeless individuals by identifying their own patients who may be homeless or at risk of becoming homeless, educating these patients about available resources in the community, treating their health problems, and increasing access to long-acting reversible contraceptives (ACOG, 2016).

\section{Evidence of Key Site Support}

This project required support from several community stakeholders who serve homeless women. The Assistant Dean for Faculty Practice and Community Engagement at WVU School of Nursing connected the project leader (DNP student) with several stakeholders in the community including Bartlett Housing Solutions, Monongalia County Health Department and WVU Medicine which led to connections with many others. Milan Puskar Health Right, the site where homeless women were interviewed, granted their support from project inception recognizing the value of addressing this need at a community level.

\section{Measurable Project Objectives}

See Appendix I for the two primary project aims, objectives and evaluation plan. 


\section{Results}

\section{$\operatorname{Aim} 1$}

Aim 1 was engaging community stakeholders and homeless women in developing a strategy to reduce unintended pregnancy in homeless women. Three objectives were created to meet this aim:

\section{Objective 1a}

Objective 1a was to obtain input from interviews with homeless women to help in the development of the community-based protocol. The information from the interviews was useful to guide community organizations in helping homeless women in need of prevention of unintended pregnancy.

\section{Themes from Interviews with Homeless Women}

Four homeless women were interviewed over the phone while they were at Milan Puskar Health Right in Morgantown. These interviews, lasting approximately 15 minutes per woman, provided rich data regarding their experience with unintended pregnancy and pregnancy prevention while residing in Monongalia County, WV. See Appendix J for interview questions and specific descriptors in the words of the participants.

\section{Timely and Convenient Access to Safety, Hygiene, Transportation and Help}

All the women interviewed mentioned the value of having access to a safe place, food, personal hygiene, and medical care around the clock for themselves and their child(ren). Otherwise, they find themselves on the street which is a vulnerable position for them. One of the women said, this is the time men approach her the most. The main community homeless shelter closes during the day (hours of operation 8pm-8am) and there is a homeless day program that opens daily (except Sunday) at $8 \mathrm{am}$ and closes at $4 \mathrm{pm}$ creating another complication in how to 
spend their evening time safely. Another issue mentioned was the homeless day program (the Friendship House) only allows children under the age of 2. Therefore, women who have older children cannot bring them there.

Milan Puskar Health Right, the clinic many homeless women in Morgantown access, closes at $7 \mathrm{pm}$ on Monday and $630 \mathrm{pm}$ on Wednesday, otherwise, it closes at $430 \mathrm{pm}$ and is closed over the weekend. During our phone interviews, one mentioned the stress of going to the Ruby Hospital ER and another mentioned using Ruby primarily for her obstetric care but not on a regular basis. One woman described how the stress associated with going to Ruby Hospital ER affects her desire to get care. After an ER evaluation, she usually walks to her nighttime residence (an abandoned home) — creating a prime opportunity for untrustworthy individuals to offer rides and creating unsafe circumstances for her. As a solution to these problems, one woman recommended having more accessible medical services that are open after-hours in the downtown area.

According to an article from De Bode (2015), "staying clean is part of a daily struggle for thousands of women, including...single women, who live on the streets, where maintaining a sense of dignity is a time-consuming and potentially dangerous endeavor." The article goes on to discuss complicating aspects of being a homeless woman who "can't pee behind a tree or has a period and can't wash up..." (De Bode, 2015). One particular interviewee brought hygiene (specifically showering) to light as a top priority during her interview. She tries to get a shower at Health Right (which has one shower) as often as she can. She lives in an abandoned home, so she usually wipes down as her shower. This is a daily struggle and disappointment for her.

During the interviews, there was mention of one place to get access to lunch almost daily. But there was a recommendation to increase the number of places to be fed during the week. 
Transportation is a challenge. Some women take the bus, one has a friend who is erratically available to drive her, another mentioned wanting a bike, but these are often stolen or traded for drugs. One lady said men offer rides a lot which she tries to refuse.

\section{Housing}

These four women all had different experiences with housing. First, one woman said many of her peers see pregnancy as a way to get moved up on the housing list. Another said, she has had six children but has been homeless for three years. She mentioned her pregnancies started in a relationship with a man who had housing. After he found out about the baby, she was forced out on the street with the child. There is a general sense of hopelessness associated the possibility of getting housing. One of the women, who is currently pregnant with her long-term boyfriend, decided to stop birth control when she and her boyfriend were in housing and decided they wanted to have a child. Since then, she lost her job and their housing, and they are currently living in the homeless shelter together. They are uncertain about what they will do when the baby arrives. As mentioned previously, another woman is living in an abandoned home, but has completed an application for HUD housing. One of the women strongly believed in housing for women in particular saying, "women don't need to be on the street...”. She also suggested housing with a structured program (standards to be met to maintain their housing) for pregnant women. The program she discussed could provide stable housing during the pregnancy and possibly lead to future housing when the child arrives.

\section{Views on Pregnancy and Contraception}

Pregnancy has motivational power for homeless women. Several of them mentioned that pregnancy would create a sense of urgency to get housing sooner and proactively address their health needs. Alternatively, one woman mentioned homeless friends who are "too high to care" 
about pregnancy. Another had two friends who avoided medical care during their pregnancies due to "laziness", a warrant for their arrest, substance use, and fear of having their child taken away.

Contraception was lightly touched upon during our conversations. There appears to be conflicting views and experiences with birth control. One woman had a positive experience with the Depo-Provera injection and reports consistent use until she consciously went off to get pregnant. She felt going to the pharmacy to pick up the Depo-Provera and returning to Health Right for injection was convenient. Another said she had it mentioned to her during the syringe exchange. She got "the shot" because she thought it was the easiest thing. She also mentioned it only had to be given once or twice per year (the recommended interval for this method is every three months). She discussed her troubles with keeping up with the time and day, so pills were difficult for her. She asks the nurse at Health Right when her shot is due. She did not recall her last one and planned to ask if she was due after our conversation. One woman said condoms would be her method of choice to prevent pregnancy but says she is not currently sexually active. Another expressed a homeless woman's view as "survival", "flying by the seat of your pants", "playing craps". Therefore, planning ahead is difficult when one is getting by day to day. Not one of the interviewees mentioned long-term contraceptive methods such as IUDs or implants. The primary locations for accessing birth control they named were Health Right and "doctor at Ruby."

\section{Objective 2a}

Objective 2 a was holding a focus group with 10 community stakeholders via virtual (Zoom) and in-person attendance on Wednesday, June 24, 2020. This date was decided based on a survey sent to all stakeholders determining the best date and time for the majority of 
participants. It was a full two-hour session. There were 14 community stakeholders invited and 10 attended the focus group. Unfortunately, one community stakeholder who was scheduled to attend was unable to participate the day of the focus group due to seeing patients. Out of the three remaining, one had another meeting and two did not follow up. Themes discussed during the focus group included: interaction, barriers, prevention, opportunities and resources. The data from the focus group was utilized to create the community-based protocol. Stakeholders represent the following community organizations: Milan Puskar Health Right, Friendship House, Mon. Co. Health Department, Mon. Co. Probation Office, WV Children's Home Society, WVU Medicine Maternal Fetal Medicine Clinic, Mon. Co. Child Protective Services, West Run Housing, WVU ACE (Assist, Connect, Encourage) Program, and WV Coalition to End Homelessness.

\section{Objective 3a}

For Objective 3a, a protocol with a corresponding resource page was created from the topics discussed in the focus group. The protocol was limited to five comprehensive pages. When the data was organized, four categories emerged from the focus group discussion. The four categories include: housing/basic needs, safety, medical/mental health/substance use, and pregnancy prevention. The resource page is organized by resource categories and provides the address and phone number of the respective agencies.

\section{Aim 2}

Aim 2 was to obtain input from stakeholders on the protocol and resource page once it was created. The protocol and resource page were emailed to stakeholders and they were given one week to provide edits via email or track changes. The protocol was updated based on relevant 
edits and recommendations. They also completed a 24 question Qualtrics survey to evaluate two specific objectives:

\section{Objective 1b}

Objective $1 \mathrm{~b}$ was to measure the acceptability of the process of development of the protocol. The first step in the evaluation process was to edit the protocol and resource list. The protocol and resources were emailed to all 10 focus group members and six of the 10 participants provided edits either via email, within the survey or track changes on the document. These edits ranged from resource location edits to multiple edits within the protocol. Following the review of the protocol and resource list, the 10 focus group members all completed a Qualtrics survey (see Appendix $\mathrm{G}$ for comprehensive list of questions). The five primary ways acceptability was evaluated were: adequate representation of focus group's views in the protocol, accurate representation of the community in the focus group, openness/freedom to share ideas during the discussion, comprehensiveness and conciseness of the protocol, and time to invest in the process.

In the Qualtrics survey, there were eight questions to assess acceptability of representation and openness in the group as well as comprehensiveness of the protocol using a Likert scale of 1-5 with 5 being strongly agree. The mean for these questions was between 4.34.6. To assess comprehensiveness and the conciseness of the protocol, an opened ended was used to determine if any essential ideas from the focus group or professional experience were missing. The focus groups members responses included adding a resource for abortion services in the crisis pregnancy section, clarification of Title X Family Planning services, adding information for adolescents, and sequencing the protocol to have basic needs first rather than pregnancy prevention. Another open-ended question was used to determine if certain stakeholders were missing from the focus group. Respondents thought greater representation was needed from 
community organizations such as Christian Help, local homeless shelters, school health nurse, and Early Head Start/Right from the Start. Of note, five out of the 10 focus group members mentioned needing a representative from an inpatient setting specifically providers and discharge planners. To assess time invested, a three-item categorical scale was used. Seven responded that the meeting length of time was just right, two said too short and one said it was too long.

An unexpected measure of acceptability came through an email from one of the stakeholders requesting the opportunity to pass along this protocol and resource list to OB/GYN residents who could continue to implement this protocol through a community project during their final year of residency. Another stakeholder confirmed acceptability of the protocol through an email stating, "I will definitely be using the resource list and sharing and using the protocol with social work students to explain the complexities of assessment, referral, treatment, etc. with homeless women in this situation."

\section{Objective 2b}

Objective $2 \mathrm{~b}$ was to assess the usefulness of the protocol according to the stakeholders who attended the focus group. The usefulness was evaluated within the Qualtrics survey after the protocol was reviewed (see Appendix G for full list of survey questions). All 10 of the focus group members completed the survey. The following goals were used to evaluate the usefulness of the protocol: how effectively it addresses the needs of the population, if it includes relevant changes that are easy to implement, and if it creates a change in practice (in mentality or practice).

To evaluate the overall usefulness of the protocol, there were seven questions using a Likert scale (1-5), with 5 being strongly agree. The mean for these questions ranged from 3.84.4. In addition, there were two Likert scale questions with follow up opened ended questions. 
The first evaluating a change in their views on preventing unplanned pregnancy in homeless women by creating this protocol. The Likert scale mean score for this question was 3.5 favoring neither agree nor disagree to somewhat agree. Responses for the open-ended question included: a broadened view of opportunities for assessment and planning at different interaction points, greater awareness of available resources, and one respondent said, "I didn't really have any thoughts on women getting pregnant while homeless. It was a situation that I knew happened, but since it wasn't right in front of my face it wasn't a focus of mine. Now I think about it more often and what resources we can provide to help."

A second Likert scale with a secondary open-ended question was used to assess whether this protocol would change the current practice of the focus group members. The mean for the Likert scale responses was 3.8, with 5 being strongly agree. Focus group members mentioned the following ways it could impact their practice: engagement of other providers and stakeholders, more consistent discussion with homeless women about contraceptive care, knowledge of availability of resources will improve access to care for patients, "I will keep homeless women of childbearing age in mind when connecting with resources and services," protocol provided extra resources to call upon, and hopeful that the protocol will make it easier to coordinate resources.

\section{Discussion}

\section{Support of the Theoretical Framework}

Discovery Interviews, the theoretical framework for this project, were the foundation for establishing a rapid cycle improvement method to begin addressing the issue of unintended pregnancy in homeless women in the Monongalia County community. Through the enlightening interviews with the homeless women and rich feedback from the community stakeholders in the focus group, there was a wealth of information available to develop a community-based protocol. 
The PDSA (Plan, Do, Study, Act) cycle used within this framework aligned with each phase of this project (NHS, 2009). For this project the plan (P) included inviting homeless women and community stakeholders to share their experience, the do (D) was creating the protocol developed from this feedback, study $(\mathrm{S})$ was the evaluation of the protocol completed by the stakeholders, and act (A) was the edits and changes made to the protocol based on their responses. The input from homeless women and those who serve and care for them in the community was essential to developing this method for incremental change. This framework is ideal for engaging those who deal with this problem in creating solutions to the problem.

\section{Connecting the Literature}

The feedback from the women and the focus group also aligns with the available literature. The basic needs that pre-occupy a homeless woman's daily life are ultimately universal (safety, shelter, food, and hygiene) (ACOG, 2016; Kennedy et al., 2014). As mentioned during the interviews, this creates significant barriers in addressing challenges such as accessing regular medical care and getting contraception which requires making appointments, getting transportation to appointments and attending follow up (Gelberg et al., 2008). If their basic needs are unmet, it may be difficult to create space for other priorities. In order to screen these needs, one of the focus group members suggested asking, "What is most important to you right now?" By addressing her top priorities, this may open a door to discuss other important life needs.

Another layer noted in the literature and through the interviews with homeless women was the undercurrent of untreated mental illness and/or substance use disorder that pervade this vulnerable population (SAMSHA, 2011; ACOG, 2016). These issues are often aggravated by fear of legal consequences and lack of housing and inability to gain ground to address these needs. As mentioned by National Coalition for the Homeless (2009), many women may be in 
unsafe relationships and lack a trusted individual to help them get the care they need. Another idea derived from the focus group was identifying an advocate who can attend appointments and/or assist in accessing resources as a helpful method to close this gap.

Another complex aspect of preventing unintended pregnancy in homeless women is their varied life experience and views on pregnancy and contraception. Women have differing levels of education on contraception, available methods and their effectiveness, and required follow up. In the interviews, this was demonstrated by the woman who stated Depo-Provera injection was only due once or twice per year when the administration interval is every three months. There is limited knowledge about long-acting reversible methods and many women are using the least effective methods (i.e. condoms) (Corey et al., 2017). An important point mentioned during the focus group was the value of community-based sex and contraceptive education and incorporating men into these conversations to help them understand available methods and to have these discussions with their significant other.

\section{Gaps to Close}

The focus group was well-attended but still lacked several vital stakeholders some of which were invited but unable to attend. A particular missing link was an inpatient provider and/or discharge planner. Many of the stakeholders recognized during the group and through their evaluations the key part in-patient care plays in the homeless community. Because many of the homeless women have difficulty with follow up, they regularly seek acute treatment as a source of regular care (i.e. ED) (ACOG, 2016). In addition, the inpatient setting provides an opportunity to have a captive audience with this vulnerable population. Not only can they provide an assessment, but they can provide care in a more immediate and comprehensive fashion including discharge planning to coordinate emergency housing, contraceptive access and connection to 
community resources. An OB/GYN and nurse midwife from WVU were invited to the focus group, but their patient commitments took precedence.

In addition to missing key stakeholders, the focus group expressed a desire to make stronger connections with other community stakeholders to help homeless women prevent unintended pregnancy in their community. Through the survey, eight out of 10 focus group participants expressed a desire to participate in a task force if one was formed. The stakeholders invited all seemed to be invested in this issue, but their partnerships in addressing this problem were either non-existent or fragmented.

\section{Recommendations}

The protocol for this project was developed by several stakeholders representing a variety of community organizations, but the key site for interviewing homeless women and providing two representatives for the focus group was Milan Puskar Health Right. Their central downtown location, trusted reputation in the homeless community, syringe exchange program, drop-in center, primary care and social services make them a cornerstone for the sustainability of this project. Their leadership will be necessary to continue to develop the protocol and strengthen community collaborations to provide more homeless women in Morgantown the "community of care" this project intended to create.

This project should be continued. The protocol developed from this project was comprehensive and concise based on the SBIRT format (screening, brief intervention and referral to treatment) which is familiar to these stakeholders. It is a quick method for screening women, providing a brief intervention and connecting them to specific community organizations in their community (Monongalia County). The additional resource page of community services is a living document that could easily be edited by those who utilize it especially if services change 
or grow through the years. The focus group was well attended despite the circumstances of a change in date and the COVID-19 pandemic. The protocol was also well received by the focus group members according to their survey responses on its acceptability and usefulness. In addition, one of the focus group participants specifically indicated they would use the protocol and resource list in their practice, one offered to find a way to implement it in the community and another later requested the project be shared during a community collaborative meeting.

There are several ongoing evaluations that will add value to this project. First, once this project is finalized the protocol and resource page can be made widely available to community organizations who serve homeless women. Once implemented, evaluations must be made on its impact on patient care. In addition, revisions must be considered and evaluated to further improve outcomes. This could be assessed in a similar fashion from interviews with homeless women in the community and the stakeholders serving them (another PDSA cycle).

This project fits well into the workplan developed by the Morgantown City Council to create a strategic plan for addressing homelessness and addiction problems in the city (Brake, 2019). Their four-pillar approach aligns with the goals of this project. The first being community engagement with private and public leaders who may be able to provide solutions (focus group). The second being a current assessment of the gaps and needs in the community (interviews/focus group discussion). Third, to have a coordinated response which entails partnerships across many different organizations (outcomes of the protocol/plan). Finally, sustainable solutions which include treatment opportunities and housing options (referral to treatment list in protocol with resource list). Though this project focuses on a particular group within the homeless population, its mission aligns with the Morgantown City Council's plan to care for and reduce barriers in this vulnerable population through a community-based response. 
In addition to leaders at the City Council, future phases of this project will be dependent on a project champion to foster development of the protocol and stronger collaboration with other community organizations. As mentioned above, leaders at Milan Puskar Health Right are poised to help lead this effort. Other important contributors are the stakeholders from this focus group, who are already invested and interested in continued participation, and the recruitment of additional stakeholders (i.e. in-patient representatives) who were missing in this initial meeting. This project could easily be carried on by another DNP student or health professional student interested in this important issue and who feels a burden to continue this work into community implementation and evaluation.

The model of this project has potential to be replicated in cities and counties outside Monongalia County. With adequate interest and participation, this project's structure lends itself to rapid cycle improvement (PDSA cycle). As mentioned in the theoretical framework of Discovery Interviews, there is value in listening to patient experiences coupled with joining stakeholders to share their experiences and ideas to create solutions for the needs of those they serve (NHS, 2009). Depending on the project location, the community's needs and solutions would likely be different from this one and unique to their population and availability of community resources but the process of development could be the same.

\section{Conclusion}

The project started with inspiration from one patient seen in a free clinic in Morgantown. From that one patient, there were interviews, a focus group and now a protocol developed to try to address her unique needs in regard to being homeless and trying to prevent an unintended pregnancy in her life. This project is in its infancy. The ultimate goal is for this patient and the many other homeless women residing in Monongalia County to, one day, have a welcoming, 
trustworthy, collaborative and comprehensive community of care that can help them thrive rather than just survive in their current circumstances. In time, providing women who are currently homeless a stable and healthy environment for them and their children to live, grow and value their lives in a new way.

\section{Attainment of the Doctor of Nursing Practice Essentials}

\section{Essential I. Scientific Underpinnings for Practice}

Through previous study, it has been proven that homeless women are more at risk for unintended pregnancy and poor outcomes. Therefore, this project uses evidence from previous studies to create a plan to address an unmet need at a community and system level.

\section{Essential II. Organizational and Systems Leadership for Quality Improvement and}

\section{Systems Thinking}

Quality improvement undergirds the basis of this protocol. Its creation is meant to build on and improve the current practices that are in place to reduce unplanned pregnancy in homeless women. This project is unique because it seeks to address this issue through a comprehensive community-based approach rather than through fragmentation of services.

\section{Essential III. Clinical Scholarship and Analytical Methods for Evidence-Based Practice}

This protocol will emphasize the use of evidence-based and patient-centered materials to educate homeless women and their partners on contraception. Through the use of the Discovery Interviews framework and focus groups, effective interventions created by the stakeholders can be used to address this need.

Essential IV. Information Systems/Technology and Patient Care Technology for the Improvement and Transformation of Health Care 
The protocol will be in a modifiable digital platform that can easily be updated and shared. Virtual conferencing was an effective method to meet with other stakeholders who could not attend in person.

\section{Essential V. Health Care Policy for Advocacy in Health Care}

This protocol engages key community stakeholders whose work directly impacts health policy. The project lead (DNP student) plans to share the finalized protocol with the Morgantown City Council to consider implementing with their workplan to address homelessness and addiction in the city.

Essential VI. Interprofessional Collaboration for Improving Patient and Population Health Outcomes

This project incorporates a variety of healthcare providers and community service providers to create a network of care for the homeless women who can address unintended pregnancies.

\section{Essential VII. Clinical Prevention and Population Health for Improving the Nation's}

\section{Health}

Prevention and population health are the foundation for this project. It is a proactive effort to address a public health issue through a framework that is patient centered.

\section{Essential VIII. Advanced Nursing Practice}

This project presents an opportunity to be a partner with and give a voice to a vulnerable patient population and the caregivers they interface with in the community. If this community-based protocol is effective, it could be replicated in similar populations by other DNP students. 


\section{References}

American College of Obstetricians and Gynecologists (ACOG). (2013, October, reaffirmed 2016). Healthcare for homeless women committee opinion, No. 576.

https://www.acog.org/clinical/clinical-guidance/committeeopinion/articles/2013/10/health-care-for-homeless-women

Anderson, S., Frerichs, L., Kaysin, A., Wheeler, S. B., Halpern, C.T., \& Lich, K. H. (2019). Effects of two educational posters on contraceptive knowledge and intentions. Obstetrics \& Gynecology, 113 (1), 53-62. doi: 10.1097/AOG.0000000000003012

Brake, P. J. (2019, November 22). Workplan for addressing homelessness and addiction problems in downtown [Memorandum]. Morgantown City Council.

https://www.morgantownwv.gov/DocumentCenter/View/3145/Homelessness-andAddiction-Strategy-Workplan---Morgantown

Center for Disease Control and Prevention. (2015). Unintended pregnancy prevention. Retrieved from https://www.cdc.gov/reproductivehealth/unintendedpregnancy/index.htm

Corey, E.K., Frazin, S., Heywood, S., \& Haider, S. (2017). Homeless women's desire for and barriers to obtaining effective contraception. Contraception, 96(4), 287. Retrieved from https://www.contraceptionjournal.org/article/S0010-7824(17)30300-1/abstract

Federal Interagency Forum on Child and Family Statistics. (2018). America's children in brief: key national indicators of well-being, 2018: homelessness. Retrieved from https://www.childstats.gov/americaschildren/homelessness.asp\#f16

Gelberg L., Lu, M.C., Leake, B.D., Andersen, R.M., Morgenstern H., Nyamathi A.M. (2008). Homeless women: who is really at risk for unintended pregnancy? In Maternal Child 
Health Journal, 12(1), 52-60. Retrieved from

https://www.ncbi.nlm.nih.gov/pubmed/18026826

Guttmacher Institute. (2014). State facts about unintended pregnancy: West Virginia. Retrieved from https://www.guttmacher.org/sites/default/files/factsheet/wv_15.pdf

Health Care for the Homeless Clinicians' Network. (2012). Decreasing unintended pregnancy among women experiencing homelessness. Healing Hands, 16(4). Retrieved from http://www.nhchc.org/wp-content/uploads/2012/10/Fall2012HealingHands.pdf

Health Care for the Homeless Clinicians' Network. (2001). Pregnant and homeless. Healing Hands, 5(4). Retrieved from http://www.nhchc.org/wpcontent/uploads/2012/02/August2001HealingHands.pdf

Kennedy, S., Grewal, M., Roberts, E. M., Steinauer, J., \& Dehlendorf, C. (2014). A qualitative study of pregnancy intention and the use of contraception among homeless women with children. Journal of health care for the poor and underserved, 25(2), 757-770. doi:10.1353/hpu.2014.0079

National Coalition for the Homeless. (2009, July). Homeless families with children. https://www.nationalhomeless.org/factsheets/families.html

National Healthcare for the Homeless Council. (2019). What is the official definition of homelessness? Retrieved from https://www.nhchc.org/faq/official-definition$\underline{\text { homelessness/ }}$

National Health Service Improvement. (2009, August). Learning from patient and carer experience: a guide to using discovery interviews to improve care. Retrieved from https://www.england.nhs.uk/improvement-hub/wpcontent/uploads/sites/44/2017/11/Discovery-Interview-Guide.pdf 
O. Nyumba, T., Wilson, K., Derrick, C., \& Mukherjee, N. (2018). The use of focus group discussion methodology: Insights from two decades of application in conservation. Methods in Ecology and Evolution, 9(1), 20-32. https://doi.org/10.1111/2041$\underline{210 X .12860}$

Saver, B.G., Weinreb, L., Gelberg, L., \& Zerger S.(2012). Provision of contraceptive services to homeless women: results of a survey of health care for the homeless providers. Women \& Health, 52(2), 151-161. https://doi.org/10.1080/03630242.2011.649829

Smid, M., Bourgois, P., \& Auerswald, C. L. (2010). The challenge of pregnancy among homeless youth: reclaiming a lost opportunity. Journal of health care for the poor and underserved, 21(2 Suppl), 140-156. doi:10.1353/hpu.0.0318

Substance Abuse and Mental Health Services Administration. (2011). Current statistics on the prevalence and characteristics of people experiencing homelessness in the United States. [Data set]. SAMHSA. https://www.samhsa.gov/sites/default/files/programs_campaigns/homelessness programs _resources/hrc-factsheet-current-statistics-prevalence-characteristics-homelessness.pdf

The Ohio State University. (n.d.). Assessing protocol feasibility: scientific value and the feasibility of managing a study. Retrieved from https://ccts.osu.edu/content/assessingprotocol-feasibility

United States Department of Health and Human Services, Office for Human Research Protections. (2018, July). Scholarly and journalistic activities deemed not to be research: 2018 requirements. https://www.hhs.gov/ohrp/regulations-and-policy/requests-forcomments/draft-guidance-scholarly-and-journalistic-activities-deemed-not-to-beresearch/index.html 
University of Wisconsin-Madison, Institute for Clinical and Translational Research. (n.d.). Protocol feasibility. Retrieved from https://ictr.wisc.edu/protocol-feasibility/

West Virginia Department of Health and Human Services, Bureau for Public Health, Office of Maternal, Child and Family Health (2018, June). Pregnancy risk assessment monitoring system (PRAMS) [Data Set]. http://www.wvdhhr.org/wvprams/pdf/PRAMS_2016.pdf 


\section{Appendix A}

\section{Criteria for Homeless Women Being Interviewed}

This interview is for women if:

1. Female between age 18-45.

2. You consider yourself homeless or have been WITHOUT a permanent nighttime residence at any point over the past 2 years. 


\section{Appendix B}

\section{Journalistic Phone Interview Questions for Homeless Women}

1. What are the main challenges of being a homeless woman in Mon County?

2. What do you think it would like to be homeless and pregnant in this community?

3. What do you think is the best way to prevent unintended pregnancy? Do you think other women who are homeless would agree?

4. What do you think is the main reason unintended pregnancies happen in homeless women?

5. Do you think Mon County is helpful to women who are homeless? How?

6. What about women who are homeless and pregnant? How?

7. How do you think this community could improve in helping women who are homeless to prevent unintended pregnancy? 


\section{Appendix C}

\section{List of Community Stakeholders}

Nurse Practitioner from Monongalia Health Department

Probation Officer from the Monongalia Correctional System

Local Nurse Practitioner in Maternal-Fetal Medicine (WVU)

Social Worker from homeless day program (Friendship House)

Nurse from local free clinic (Milan Puskar Health Right)

Representative from state coalition to end homelessness (WV Coalition to End Homelessness)

Professor/Nurse from healthcare for the homeless initiative (WVU MUSHROOM Rounds)

Representative from Child Protective Services in Monongalia County

Representative from foster care system in Monongalia County (WV Children's Home Society)

Program Coordinator for ACE Program (WVU)

Social Worker from local mental health facility (Chestnut Ridge Center) (Committee

Member/Content Expert) 


\section{Appendix D}

\section{Focus Group Discussion Question}

Introduction: Thank you for coming today. The reason we are meeting today is to gather people from different community organizations who serve homeless women of child-bearing age in unique ways in Monongalia County. We are having a conversation about how to prevent unintended pregnancy specifically in this vulnerable population. From my experience as a nurse practitioner in Morgantown, I learned unplanned pregnancy in homeless women is a problem. The goal of this meeting is to create a protocol that we all can use in our community settings in Morgantown. If effective, it may be useful in communities beyond Morgantown to help these marginalized women and their children. Through our open discussion and brainstorming today in addition to the feedback I received from interviewing homeless women, this project hopes to develop a community-based protocol to prevent unintended pregnancy in homeless women. The goal of the protocol is to be reflective of your ideas and accessible and useful to many organizations serving homeless women in our community. Thank you so much for being here. Your advocacy has preceded you and we hope today will provide an opportunity to share ways we can make more positive changes.

1. Tell me about your interaction with homeless women...

a. How often do you see them?

b. How do you serve them?

2. Because you interact with these women, what are your thoughts about the opportunity to prevent unintended pregnancy in homeless women?

3. What are your ideas about things that could be changed to help these women take on this problem? 
4. Are there things your organization is doing currently to prevent unplanned pregnancy in homeless women? What are your thoughts about what your organization could do to prevent this?

5. Are you familiar with any other ways other organizations are addressing this issue? What are they?

6. From your perspective, what are some practical ways we can close gaps you have seen in our community or your organizations to prevent unintended pregnancy in homeless women?

a. Location>intervention (Where? /What?)

7. What do you think are barriers for homeless women in preventing unintended pregnancy in our community?

a. for the women as individuals

b. on a system/community level

8. What are your ideas for ways to resolve those barriers?

9. What are ways we could all work together to take on this problem?

a. Who would you reach out to help prevent this problem?

10. Any other ideas to help reduce unintended pregnancy in homeless women in Mon County?

11. What resources do you think we need to prevent this problem better?

12. Who else should be involved in this conversation? Is there anyone missing from this group that would be helpful? Is there a group that is not represented? 


\section{Appendix E \\ Protocol}

\section{PROTOCOL for Preventing Unintended Pregnancy in Homeless Women in Monongalia County, West Virginia*}

\begin{tabular}{|c|c|c|}
\hline CREENING & $\begin{array}{l}\mathbb{B}_{\text {RIEF }} \\
\mathbb{E}_{\text {NTERVENTION }}\end{array}$ & $\begin{array}{l}\mathbb{R}_{\text {EFERRAL TO }} \\
\mathbb{\prod} \text { REATMENT (SEE RESOURCE LIST) }\end{array}$ \\
\hline $\begin{array}{l}\text { Housing/Basic } \\
\text { Needs: } \\
\text { 1. What is most important } \\
\text { to you right now? } \\
\text { 2. Do you need help with } \\
\text { housing or other basic } \\
\text { needs (i.e. food, } \\
\text { transportation, } \\
\text { hygiene)? } \\
\text { 3. Do you need an } \\
\text { interpreter? } \\
\text { 4. Do you have problems } \\
\text { with reading (literacy } \\
\text { screening)? }\end{array}$ & $\begin{array}{l}\text { - Connect woman with appropriate housing and } \\
\text { food resources } \\
\text { - Utilize a standardized transportation service } \\
\text { guide to help clients get to healthcare } \\
\text { facilities, service providers, and shelter } \\
\text { locations } \\
\text { - Discuss with client safe places in the } \\
\text { community where women can go when } \\
\text { shelters are closed. } \\
\text { - Verify language services and low literacy } \\
\text { resources are available when needed. } \\
\text { Identify an advocate to accompany client to } \\
\text { access care or services and assist with needed } \\
\text { resources. } \\
\text { - Have identified advocate present to listen to } \\
\text { discharge instructions (when relevant). } \\
\text { Develop a coordinated system to access } \\
\text { resources and coordinate care by utilizing } \\
\text { case workers in homeless shelters or through }\end{array}$ & $\begin{array}{l}\text { Housing: } \\
\text { - } \text { Bartlett Housing Solutions/West Run } \\
\text { - } \text { Caritas House (for women with HIV/AIDS) } \\
\text { - } \text { Fairmont-Morgantown Housing Authority (local } \\
\text { HUD agency) } \\
\text { - North Central Community Action Agency (case } \\
\text { management) } \\
\text { - Sober Living } \\
\text { WV Coalition to End Homelessness } \\
\text { (WVCEH) } \\
\circ \quad \text { Rapid Rehousing \& Outreach } \\
\circ \quad \text { Permanent Supportive Housing } \\
\circ \quad \text { Coordinated Entry } \\
\circ \quad \text { Housing Opportunities for Persons with } \\
\quad \text { AIDS (HOPWA) } \\
\circ \quad \text { Projects for Assistance in Transition } \\
\text { from Homelessness (PATH) Street } \\
\text { Outreach } \\
\circ \quad \text { Other private funding to assist in } \\
\text { diverting households away from the }\end{array}$ \\
\hline
\end{tabular}




\begin{tabular}{|c|c|c|}
\hline & $\begin{array}{l}\text { other community agencies providing case } \\
\text { management. } \\
\text { Consider utilizing mobile outreach units to } \\
\text { access care (medical or mental health care). }\end{array}$ & $\begin{array}{l}\text { homeless services system, address family } \\
\text { homelessness and connect persons with } \\
\text { opioid addiction to housing and } \\
\text { treatment } \\
\text { - Care Management at WVU Medicine (after } \\
\text { recent discharge) } \\
\text { - Care Coordination at Mon Health Medical Center } \\
\text { (after recent discharge) } \\
\text { Food: } \\
\text { Some of the below resources also provide hygiene } \\
\text { products, please call for details. } \\
\text { - Canyon Presbyterian Food Pantry } \\
\text { - Caritas House Food Pantry } \\
\text { - Catholic Charites of WV } \\
\text { - Christian Help } \\
\text { - Circle of Friends, Wesley United Methodist } \\
\text { - Church, The Foundry (weekend meals) } \\
\text { - Clay-Battelle Area Family Services } \\
\text { - Monenant Evangelical Methodist Church } \\
\text { - Morgantown Community Kitchen at Trinity } \\
\text { - Episcopal (“The Red Door”)- (weekday lunch) } \\
\text { - Sock Forge Presbyterian Church } \\
\text { - Salvation Army (food pantry and weekday meals } \\
\text { - Scott's Run Resettlement House } \\
\text { - St. Ursula's Food Pantry } \\
\text { - LogistiCare for Medicaid members for } \\
\text { - Mountain Line Transit Authority }\end{array}$ \\
\hline $\begin{array}{l}\text { Safety: } \\
\text { 1. Do you feel safe? }\end{array}$ & $\begin{array}{l}\text { - Discuss with client safe places in the } \\
\text { community where women can go when } \\
\text { shelters are closed. }\end{array}$ & $\begin{array}{l}\text { Sexual Assault, Domestic Violence, Case Management } \\
\text { - Legal Aid of West Virginia (Free Civil Legal } \\
\text { Services) } \\
\end{array}$ \\
\hline
\end{tabular}




\begin{tabular}{|c|c|c|}
\hline $\begin{array}{l}\text { 2. } \begin{array}{l}\text { Do you have a safe } \\
\text { person you trust? }\end{array} \\
\text { 3. Are you being } \\
\text { physically, emotionally } \\
\text { or sexually hurt by } \\
\text { someone? } \\
\text { 4. Have you exchanged } \\
\text { sex for money, goods } \\
\text { or services? }\end{array}$ & $\begin{array}{l}\text { - Communicate to client she is in a "safe place" } \\
\text { and welcome "as they are" in your clinic or } \\
\text { organization. } \\
\text { - Connect with domestic violence services to } \\
\text { free her from any unsafe environment. } \\
\text { - Be aware of services in the area for sexual } \\
\text { assault examinations. } \\
\text { - Identify an advocate to accompany client to } \\
\text { access care or services and assist with needed } \\
\text { resources. }\end{array}$ & $\begin{array}{l}\text { - Morgantown Police Department } \\
\text { - } \text { Rational Human Trafficking Hotline } \\
\text { (RDVIC) } \\
\text { - Sexual Assault Exams at WVU Hospital (Ruby), } \\
\text { - Mon Health ED or RDVIC } \\
\text { WV Coalition to End Homelessness (several } \\
\text { resources) } \\
\text { Safe Places during the Day: } \\
\text { - Morgantown Public Library } \\
\text { - Friendship House } \\
\text { - Milan Puskar Health Right }\end{array}$ \\
\hline $\begin{array}{l}\text { Medical/Mental } \\
\text { Health/Substance } \\
\text { Use: } \\
\text { 1. Are you receiving } \\
\text { medical, mental health } \\
\text { or substance use care? } \\
\text { 2. Would you benefit } \\
\text { from any of these } \\
\text { services? } \\
\text { 3. Do you have } \\
\text { insurance? } \\
\text { 4. What would you like to } \\
\text { see different in your } \\
\text { life? }\end{array}$ & $\begin{array}{l}\text { - Identify an advocate to accompany client to } \\
\text { access care or services and assist with needed } \\
\text { resources. } \\
\text { - Have identified advocate present to listen to } \\
\text { discharge instructions (when relevant). } \\
\text { Discuss with client relevant clinic availability } \\
\text { for scheduling appointments including same- } \\
\text { day and walk-in times (verify times before } \\
\text { scheduling or confirming with client). } \\
\text { - Consider utilizing mobile outreach units to } \\
\text { access care (medical or mental health care). } \\
\text { Cultivate relationships with recovery coaches } \\
\text { in community organizations to help women } \\
\text { with substance use. } \\
\text { Verify language services and low literacy } \\
\text { resources are available. } \\
\text { Utilize motivational interviewing to identify } \\
\text { areas in their life where they would like to } \\
\text { seek help or see change. }\end{array}$ & $\begin{array}{l}\text { Health Insurance } \\
\text { - } \quad \text { DHHR to apply for Medicaid } \\
\text { - } \text { exams, STDily Planning Program (Title X) covers } \\
\text { see contraceptive services box for locations* } \\
\text { Medical } \\
\text { - Milan Puskar Health Right } \\
\text { - Clay-Battelle Community Health Center } \\
\text { - Mon Health Primary Care (several locations) } \\
\text { - Mon Health Medical Center Care Coordination } \\
\text { - } \text { (after recent discharge, clarify plan) } \\
\text { - WVU Medicine Primary Care (several locations) } \\
\text { - WVU Medicine Care Management (after recent } \\
\text { Contraceptive Services } \\
\text { See box below on Contraceptive Services* } \\
\text { Mental Health Care and Substance Use Disorder } \\
\text { Treatment } \\
\text { - Ascension Recovery Services } \\
\text { - Chestnut Ridge Hospital } \\
\text { - Help4WV (hotline for service coordination) }\end{array}$ \\
\hline
\end{tabular}




\begin{tabular}{|c|c|c|}
\hline & & $\begin{array}{l}\text { - Legal Aid of West Virginia (Behavioral Health } \\
\text { - } \quad \text { Advocacy) } \\
\text { - } \quad \text { Milan Puskar Health Right } \\
\text { - Valley HealthCare System } \\
\text { - Wedgewood Psychiatry } \\
\text { - WVU Medicine: United Summit Center } \\
\text { Substance Use Programs } \\
\text { - Alcoholics Anonymous } \\
\text { - Narcotics Anonymous } \\
\text { - Celebrate Recovery } \\
\text { - SAMHSA National Helpline } \\
\text { Residential Treatment for SUD } \\
\text { - WVU Medicine Center for Hope and Healing - } \\
\text { (women with and without children-contact } \\
\text { them for details) }\end{array}$ \\
\hline $\begin{array}{l}\text { Prevention of } \\
\text { Pregnancy: } \\
\text { 1. Are you sexually } \\
\text { active? } \\
\text { 2. What are you doing to } \\
\text { prevent pregnancy? }\end{array}$ & $\begin{array}{l}\text { - Ask women about contraception during any } \\
\text { encounter/visit. For example, at syringe } \\
\text { exchange programs or community settings } \\
\text { where she could get a referral for services. } \\
\text { - Facilitate regular conversations during and } \\
\text { after pregnancy about contraception and post- } \\
\text { partum plans. } \\
\text { - Assess desires and understanding of } \\
\text { contraceptive methods to prevent pregnancy } \\
\text { (i.e. LARC education). } \\
\text { - Offer methods of birth control that require } \\
\text { less maintenance (i.e. pills vs. IUD). } \\
\text { - Provide her with accessible educational } \\
\text { resources on contraception } \\
\text { - Provide education on topics such as consent, } \\
\text { sex and pregnancy prevention } \\
\text { Integrate men into the conversation on } \\
\text { contraception-during clinical visits and }\end{array}$ & $\begin{array}{l}\text { Contraceptive Services } \\
\text { - Clay Battelle Community Health Center* } \\
\text { - } \text { Dr. Susan Capelle } \\
\text { - Milan Puskar Health Right* } \\
\text { - Mon Health OB/GYN } \\
\text { - Monongalia County Health Department* } \\
\text { - } \text { Pineview Gynecology } \\
\text { - WVU OB/GYN } \\
\text { *Family Planning (free services for under-insured and } \\
\text { uninsured women) } \\
\text { Pregnancy Care } \\
\text { - Mon Health OB/GYN } \\
\text { - Mon Health Medical Center Care Coordination } \\
\text { - (after recent discharge, clarify post-partum plan) } \\
\text { - WVU Medicine OB/GYN } \\
\text { Pregnancy Medicine Care Management (after recent } \\
\text { discharge, clarify postpartum plan) }\end{array}$ \\
\hline
\end{tabular}




\begin{tabular}{|c|c|c|}
\hline & $\begin{array}{l}\text { through educational sessions. Ask women to } \\
\text { invite partners when possible. } \\
\text { For inpatient providers: Discuss pregnancy } \\
\text { prevention with homeless women in the in- } \\
\text { patient setting and make contraceptive } \\
\text { services available prior to discharge. } \\
\text { - Be aware of what contraceptive methods are } \\
\text { readily available at the sites where they access } \\
\text { care. } \\
\text { For Family Planning/Title X providers: } \\
\text { Identify opportunities to streamline } \\
\text { paperwork required by Title X. } \\
\text { Be aware of clinics providing same day } \\
\text { appointments for contraceptive care. } \\
\text { Facilitate a monthly women's educational } \\
\text { day/contraceptive clinic at a local facility or } \\
\text { church. Open it to their children for play, } \\
\text { offer lunch, educational sessions and } \\
\text { appointments to get contraceptive care. } \\
\text { Advertise primarily where homeless women } \\
\text { may be (i.e. shelters). } \\
\text { Develop relationships with discharge hospital } \\
\text { to coordinate post-partum contraceptive plan } \\
\text { in outpatient settings. } \\
\text { Inpatient Care Coordination: Cultivate a } \\
\text { direct relationship with a staff member at WV } \\
\text { Family Planning/Title X to enroll the patient } \\
\text { in the program and provide information about } \\
\text { available services/locations. }\end{array}$ & $\begin{array}{l}\text { - Right from the Start } \\
\text { - WV Healthy Start/Helping Appalachian Parents } \\
\text { and Infants (HAPI) } \\
\text { Adoption Services } \\
\text { - WV Children's Home Society }\end{array}$ \\
\hline
\end{tabular}

*Created on 6/24/2020 by Jessica Wukasch, MSN, NP-C

Edits from Focus Group completed on 7/13/2020 
Appendix F: Resource List

\section{REFERRAL TO TREATMENT RESOURCES*}

\begin{tabular}{|c|c|}
\hline \multicolumn{2}{|c|}{ HOUSING } \\
\hline $\begin{array}{l}\text { Bartlett Housing Solutions/West Run } \\
10 \text { West Run Road } \\
\text { Suite } 200 \\
\text { Morgantown, WV } 26508 \\
\text { 304-292-0101 }\end{array}$ & $\begin{array}{l}\text { North Central Community Action Agency } \\
\text { (Monongalia County contacts Marion Co.) } \\
215 \text { Scott Place } \\
\text { Fairmont, WV } 26554 \\
\text { 304-366-6543 }\end{array}$ \\
\hline $\begin{array}{l}\text { Caritas House (for women with HIV/AIDS) } \\
391 \text { Scott Avenue } \\
\text { Morgantown, WV } 26508 \\
\text { 304-985-0021 }\end{array}$ & $\begin{array}{l}\text { Sober Living } \\
\text { West Virginia Sober Living } \\
\text { 206 Spruce St. } \\
\text { Morgantown, WV } 26505 \\
\text { 304-413-4300 }\end{array}$ \\
\hline $\begin{array}{l}\text { Fairmont-Morgantown Housing Authority } \\
\text { (local HUD agency) } \\
103 \text { 12th Street } \\
\text { Fairmont, WV } 26554 \\
304-363-0860\end{array}$ & $\begin{array}{l}\text { WV Coalition to End Homelessness } \\
\text { (HUD Continuum of Care) } \\
527 \text { E Main Street } \\
\text { Bridgeport, WV } 26330 \\
\text { 304-842-9522 } \\
\text { Coordinated Entry Intake Line 1-833-722-2014 }\end{array}$ \\
\hline $\begin{array}{l}\text { HUD Housing Application (see above for local resource) } \\
\text { State Home Office: } \\
\text { 414 Summers Street, Suite } 110 \\
\text { Charleston, WV 25301 } \\
800-225-5342\end{array}$ & $\begin{array}{l}\text { WVU Care Management (if recently hospitalized) } \\
1 \text { Medical Center Drive } \\
\text { Morgantown, WV } 26506 \\
304-598-4183\end{array}$ \\
\hline
\end{tabular}




\begin{tabular}{|l|l|}
\hline Mon Health Medical Center Care Coordination (if & \\
recently hospitalized) & \\
1200 J.D. Anderson Drive & \\
Morgantown, WV 26505 & \\
$304-598-1537$ & \\
\hline
\end{tabular}

\begin{tabular}{|c|c|}
\hline \multicolumn{2}{|c|}{ FOOD } \\
\hline $\begin{array}{l}\text { Canyon Presbyterian Food Pantry } \\
18 \text { Whipkey Lane } \\
\text { Morgantown, WV } 26508 \\
304-594-2143\end{array}$ & $\begin{array}{l}\text { First Presbyterian Church (Sunday morning breakfast) } \\
456 \text { Spruce Street } \\
\text { Morgantown, WV } \\
304-296-8235\end{array}$ \\
\hline $\begin{array}{l}\text { Caritas House Food Pantry (hygiene items available) } \\
391 \text { Scott Avenue } \\
\text { Morgantown, WV } 26508 \\
\text { 1-304-985-0021 }\end{array}$ & $\begin{array}{l}\text { Monongalia County Starting Points } \\
\text { 901 Mylan Park Lane } \\
\text { Morgantown, WV } 26501 \\
\text { 304-983-2432 }\end{array}$ \\
\hline $\begin{array}{l}\text { Catholic Charities of WV (Monongalia County } \\
\text { Outreach) } \\
827 \text { Fairmont Road, Suite } 203 \\
\text { Morgantown, WV 26501 } \\
\text { 304-292-6597 }\end{array}$ & $\begin{array}{l}\text { The Pantry Plus More } \\
9 \text { Rousch Drive } \\
\text { Morgantown, WV } 26501 \\
\text { 304-282-1123 }\end{array}$ \\
\hline $\begin{array}{l}\text { Christian Help (emergency financial assistance, food } \\
\text { pantry, clothing) } \\
219 \text { Walnut Street } \\
\text { Morgantown, WV } 26505 \\
\text { 1-304-296-0221 }\end{array}$ & $\begin{array}{l}\text { Rock Forge Presbyterian Church } \\
3085 \text { Earl L Core Rd. } \\
\text { Morgantown, WV } 26508 \\
\text { For intake, call 304-241-4831 }\end{array}$ \\
\hline $\begin{array}{l}\text { Circle of Friends, Wesley United Methodist Church, The } \\
\text { Foundry (weekend meals) } \\
503 \text { North High Street }\end{array}$ & $\begin{array}{l}\text { Salvation Army (thrift store, soup kitchen, social services) } \\
\text { food pantry and weekday meals 4-5pm } \\
1264 \text { University Ave }\end{array}$ \\
\hline
\end{tabular}




\begin{tabular}{|c|c|}
\hline $\begin{array}{l}\text { Morgantown, WV } 26505 \\
304-292-9485\end{array}$ & $\begin{array}{l}\text { Morgantown, WV } 26505 \\
\text { (304) 296-3525 }\end{array}$ \\
\hline $\begin{array}{l}\text { Clay Battelle Area Family Services } \\
\text { Old Blacksville Elementary } \\
6061 \text { Mason Dixon Highway } \\
\text { Blacksville, West Virginia } 26521 \\
\text { 304-432-7200 }\end{array}$ & $\begin{array}{l}\text { Scott's Run Resettlement House (food pantry and personal } \\
\text { hygiene items) } \\
41 \text { Ladybug Drive } \\
\text { Osage, WV } 26543 \\
\text { (304) } 599-5020\end{array}$ \\
\hline $\begin{array}{l}\text { Community Kitchen, Inc. at Trinity Episcopal Church } \\
\text { (“The Red Door")-weekday lunch } \\
247 \text { Willey Street } \\
\text { Morgantown, WV } 26505 \\
\text { 304-292-7364 }\end{array}$ & $\begin{array}{l}\text { Sarah's Table: St John University Parish (Sunday mid-day } \\
\text { meal) } \\
\text { 1481 University Avenue } \\
\text { Morgantown, WV } 26505 \\
\text { 304-296-8231 }\end{array}$ \\
\hline $\begin{array}{l}\text { Covenant Evangelical Methodist Church } \\
802 \text { Greenbag Rd } \\
\text { Morgantown, WV } 26505 \\
\text { 304-292-6050 }\end{array}$ & $\begin{array}{l}\text { St. Ursula's Food Pantry } \\
87 \text { Pursglove Rd } \\
\text { Morgantown, WV } 26501 \\
\text { 304-599-3822 }\end{array}$ \\
\hline
\end{tabular}

\begin{tabular}{|l|l|}
\hline \multicolumn{2}{|c|}{ TRANSPORTATION } \\
\hline $\begin{array}{l}\text { Mountain Line Transit Authority } \\
\text { 691 Fairmont Road } \\
\text { Morgantown, WV 26501 }\end{array}$ & $\begin{array}{l}\text { LogistiCare (for Medicaid members only for transportation } \\
\text { to medical services) } \\
1-844-549-8353\end{array}$ \\
\hline
\end{tabular}




\begin{tabular}{|c|c|}
\hline \multicolumn{2}{|c|}{ SAFETY AND SUPPORT } \\
\hline $\begin{array}{l}\text { Friendship House-Health Right } \\
\text { 231 Walnut St } \\
\text { Morgantown, WV } 26505 \\
\text { 304-413-0068 }\end{array}$ & $\begin{array}{l}\text { National Human Trafficking Hotline } \\
\text { 1-888-373-7888 } \\
\text { *Text 233733 (“BeFree”)) }\end{array}$ \\
\hline $\begin{array}{l}\text { Legal Aid of West Virginia (Free Civil Legal Services) } \\
165 \text { Scott Avenue, Suite } 209 \\
\text { Morgantown, WV } 26508 \\
1-800-453-1939 \\
304-296-0001\end{array}$ & $\begin{array}{l}\text { Rape and Domestic Violence Information Center } \\
\text { (RDVIC) } \\
\text { Morgantown, WV, } 26504 \\
304-292-5100 \text { (24 hours }\end{array}$ \\
\hline $\begin{array}{l}\text { Morgantown Police Department } \\
\text { 300 Spruce St. } \\
\text { Morgantown, WV } 26505 \\
\text { 304-284-7522 }\end{array}$ & $\begin{array}{l}\text { WV Coalition to End Homelessness } \\
\text { 527 E Main Street } \\
\text { Bridgeport, WV } 26330 \\
304-842-9522\end{array}$ \\
\hline $\begin{array}{l}\text { Morgantown Public Library } \\
373 \text { Spruce Street } \\
\text { Morgantown, WV } 26505 \\
\text { 304-291-7425 }\end{array}$ & \\
\hline
\end{tabular}

\begin{tabular}{|l|l|}
\hline \multicolumn{2}{|c|}{ MEDICAL, MENTAL HEALTH AND SUBSTANCE USE TREATMENT } \\
\hline INSURANCE & \begin{tabular}{l} 
WV Family Planning Program (Title X) \\
\hline DHHR to apply for Medicaid \\
(may apply online if comfortable and have access) \\
114 S High Street, \\
Morgantown, WV 26507 \\
(304) $285-3175$
\end{tabular} \\
\hline
\end{tabular}




\begin{tabular}{|c|c|}
\hline & $\begin{array}{l}\text { 350 Capitol Street Room } 427 \\
\text { Charleston, WV } 25301 \\
\text { Telephone: (304) 558-5388 } \\
\text { Toll Free: (800) 642-8522 } \\
\text { See * in contraceptive services and list below for locations } \\
\text { to access this program }\end{array}$ \\
\hline \multicolumn{2}{|l|}{ MEDICAL } \\
\hline $\begin{array}{l}\text { Clay-Battelle Community Health Center* } \\
\text { 5861 Mason-Dixon Hwy } \\
\text { Blacksville, WV } 26521 \\
\text { 304-432-8211 }\end{array}$ & $\begin{array}{l}\text { Mon Health Primary Care - Morgantown } \\
6000 \text { Memorial Church Drive Suite A } \\
\text { Morgantown, WV } 26501 \\
\text { 304-598-7313 }\end{array}$ \\
\hline $\begin{array}{l}\text { Milan Puskar Health Right* } \\
\text { 341 Spruce Street } \\
\text { Morgantown, WV } 26505 \\
\text { 304-292-8234 }\end{array}$ & $\begin{array}{l}\text { Wedgewood Primary Care } \\
\text { Cheat Lake } \\
\text { 1300 Fort Pierpont Road Suite } 101 \\
\text { Morgantown, WV } 26508 \\
\text { 304-241-7150 } \\
\text { Suncrest } \\
\text { 1000 Mon Health Medical Park Drive } \\
\text { Suite } 1201 \\
\text { Morgantown, WV } 26505 \\
\text { 1-877-599-9401 } \\
\text { Westover } \\
\text { 6000 Memorial Church Drive } \\
\text { Westover, WV 26501 } \\
\text { 1-877-599-9401 }\end{array}$ \\
\hline $\begin{array}{l}\text { J.W. Ruby Memorial Hospital Care Management (WVU } \\
\text { Medicine) (if recently discharged to verify outpatient plan) } \\
1 \text { Medical Center Dr. } \\
\text { Morgantown, WV } 26505 \\
\text { 304-598-4183 }\end{array}$ & $\begin{array}{l}\text { WVU Medicine Primary Care } \\
855-988-2273\end{array}$ \\
\hline
\end{tabular}




\begin{tabular}{|l|l|}
\hline & University Town Centre \\
& 6040 University Town Centre Drive \\
& Morgantown, WV 26501 \\
Physician Office Center & 1 Medical Center Drive \\
& Morgantown, WV 26506 \\
& Cheat Lake Clinic \\
& 608 Cheat Road \\
& Morgantown, WV 26508 \\
& Morgantown South \\
& 250 Retail Circle \\
& Morgantown, WV 26508 \\
& WVU Medicine Primary Care \\
& 2601 Cranberry Square \\
& Morgantown, WV 26508 \\
Mon Health Medical Center Care Coordination (if recently & \\
discharged to verify outpatient plan) & \\
1200 J D Anderson Dr & \\
Morgantown, WV 26505 & \\
304-598-1537 & \\
\hline
\end{tabular}

\section{MENTAL HEALTH CARE AND SUBSTANCE USE TREATMENT}

\section{Ascension Recovery Services}

206 Spruce Street

Morgantown, WV 26505

304-241-4585

Chestnut Ridge Hospital

930 Chestnut Ridge Rd

Morgantown, WV 26505

(304) 598-6400
Milan Puskar Health Right

341 Spruce Street

Morgantown, WV 26505

304-292-8234

\section{Valley HealthCare System}

24 Hour Crisis Number 1-800-232-0020

Suicide Prevention Hotline 1-800-273-8255 


\begin{tabular}{|c|c|}
\hline & $\begin{array}{l}\text { 301 Scott Avenue } \\
\text { Morgantown, WV 26508-8804 } \\
\text { 304-296-1731 } \\
\text { New Beginnings Program } \\
820 \text { Elysian Ave. } \\
\text { Morgantown, WV } 26501 \\
\text { 304-367-1625 } \\
\text { Crisis Residential Unit } \\
\text { 301 Scott Avenue } \\
\text { Morgantown, WV } 26508 \\
\text { 304-225-2280 }\end{array}$ \\
\hline $\begin{array}{l}\text { Help4WV } \\
\text { Call 304-356-5840 } \\
\text { Text 844-435-7498 }\end{array}$ & $\begin{array}{l}\text { Wedgewood Psychiatry Associates } \\
1000 \text { Mon Health Medical Park Drive } \\
\text { Suite } 1202 \\
\text { Morgantown, WV } 26505 \\
\text { 304-599-1975 }\end{array}$ \\
\hline $\begin{array}{l}\text { Legal Aid of West Virginia (Behavioral Health Advocacy) } \\
165 \text { Scott Avenue, Suite } 209 \\
\text { Morgantown, WV } 26508 \\
\text { 1-800-453-1939 } \\
\text { 304-296-0001 }\end{array}$ & $\begin{array}{l}\text { WVU Medicine United Summit Center } \\
34 \text { Commerce Drive Suite 204-207 } \\
\text { Westover, WV } 26501 \\
\text { 304-623-5666 Extension } 5825\end{array}$ \\
\hline $\begin{array}{l}\text { MedMark Treatment Centers } \\
53 \text { Don Knotts Boulevard } \\
\text { Morgantown, WV } 26508 \\
304-284-0025\end{array}$ & \\
\hline
\end{tabular}




\begin{tabular}{|c|c|}
\hline \multicolumn{2}{|l|}{ Residential Treatment for SUD } \\
\hline $\begin{array}{l}\text { WVU Medicine Center for Hope and Healing } \\
\text { 1000 Jerry Dove Drive } \\
\text { Bridgeport West Virginia } 26330 \\
\text { 304-974-3100 } \\
681-342-3361\end{array}$ & $\begin{array}{l}\text { SAMHSA National Helpline (Treatment Referral } \\
\text { Routing Service) } \\
\text { 1-800-662-HELP (4357) }\end{array}$ \\
\hline \multicolumn{2}{|l|}{ Substance Use Programs } \\
\hline $\begin{array}{l}\text { Alcoholics Anonymous } \\
\text { 24/7 Hotline: (800) 333-5051 } \\
\text { Narcotics Anonymous } \\
\text { 1-800-766-4442 }\end{array}$ & $\begin{array}{l}\text { Celebrate Recovery } \\
\text { Suncrest United Methodist } \\
479 \text { Van Voorhis Road } \\
\text { Morgantown, WV } 26505 \\
\text { 304-599-6306 } \\
\text { Chestnut Ridge Church } \\
\text { 2223 Cheat Road } \\
\text { Morgantown, WV } 26508 \\
\text { 304-594-0548 }\end{array}$ \\
\hline
\end{tabular}

\begin{tabular}{|l|l|}
\hline \multicolumn{2}{|c|}{ CONTRACEPTIVE CARE } \\
\hline Clay-Battelle Community Health Center* & $\begin{array}{l}\text { Mon Health OB/GYN } \\
\text { 2000 Mon Health Medical Park Drive, Suite 2100 } \\
\text { 5861 Mason-Dixon Hwy } \\
\text { Blacksville, WV 26521 } \\
\text { 304-432-8211 }\end{array}$ \\
& $304-599-6811$ \\
\hline Dr. Susan Capelle & Monongalia County Health Department* \\
3496 University Avenue & 453 Van Voorhis Road \\
Morgantown, WV 26505 & Morgantown, WV 26505 \\
304-599-7075 & $304-598-5100$ \\
& \\
\hline
\end{tabular}




\begin{tabular}{|c|c|}
\hline $\begin{array}{l}\text { J.W. Ruby Memorial Hospital Care Management (if post- } \\
\text { partum and recently discharged to verify plan) } \\
1 \text { Medical Center Dr. } \\
\text { Morgantown, WV } 26505 \\
304-598-4183\end{array}$ & $\begin{array}{l}\text { Pineview Gynecology } \\
\text { 1322 Pineview Drive } \\
\text { Morgantown, WV } 26505 \\
\text { 304-599-8790 }\end{array}$ \\
\hline $\begin{array}{l}\text { Milan Puskar Health Right* } \\
\text { 341 Spruce Street } \\
\text { Morgantown, WV } 26505 \\
\text { 304-292-8234 }\end{array}$ & $\begin{array}{l}\text { WVU OB/GYN } \\
855-988-2273 \\
\text { Ruby } \\
1 \text { Medical Center Drive } \\
\text { Morgantown, WV } 26506 \\
\text { Morgantown } \\
608 \text { Cheat Road } \\
\text { Morgantown, WV } 26508 \\
\text { University Town Centre } \\
\text { 6040 University Town Centre Drive } \\
\text { Morgantown, WV 26501 }\end{array}$ \\
\hline $\begin{array}{l}\text { Mon Health Medical Center Care Coordination (if post- } \\
\text { partum and recently discharged to verify outpatient plan) } \\
1200 \text { J D Anderson Dr } \\
\text { Morgantown, WV } 26505 \\
304-598-1537\end{array}$ & $\begin{array}{l}*=\text { Family Planning/Title X clinics provide services for } \\
\text { both uninsured and under-insured individuals of } \\
\text { reproductive age seeking to prevent or plan a pregnancy or } \\
\text { require STI screening/treatment. } \\
\text { Contact Primary Care clinics listed above for availability } \\
\text { of contraceptive services at their sites. }\end{array}$ \\
\hline
\end{tabular}

\begin{tabular}{|l|l|}
\hline \multicolumn{2}{|c|}{ PREGNANCY } \\
\hline Pregnancy Care \\
\hline $\begin{array}{l}\text { Mon Health OB/GYN } \\
\text { 2000 Mon Health Medical Park Drive, Suite 2100 } \\
\text { Morgantown, WV 26505 }\end{array}$ & $\begin{array}{l}\text { WVU OB/GYN } \\
855-988-2273\end{array}$ \\
\hline
\end{tabular}




\begin{tabular}{|c|c|}
\hline $304-599-6811$ & $\begin{array}{l}\text { Ruby } \\
1 \text { Medical Center Drive } \\
\text { Morgantown, WV } 26506 \\
\text { Morgantown } \\
608 \text { Cheat Road } \\
\text { Morgantown, WV } 26508 \\
\text { University Town Centre } \\
6040 \text { University Town Centre Drive } \\
\text { Morgantown, WV } 26501\end{array}$ \\
\hline \multicolumn{2}{|l|}{ Pregnancy Programs } \\
\hline $\begin{array}{l}\text { Right from the Start } \\
\text { Burlington United Methodist Family Services } \\
\text { 1368 Anmoore Road, Suite } 102 \\
\text { Bridgeport, West Virginia } 26330 \\
\text { (304) 624-7979 } \\
\text { 1-800-642-8522 }\end{array}$ & $\begin{array}{l}\text { WV Healthy Start/Helping Appalachian Parents and } \\
\text { Infants (HAPI) } \\
\text { WVU Department of Obstetrics and Gynecology } \\
\text { 1-866-738-HAPI (4274) }\end{array}$ \\
\hline \multicolumn{2}{|l|}{ Adoption Services } \\
\hline $\begin{array}{l}\text { Children's Home Society of WV } \\
11 \text { Commerce Dr, Suite } 102 \\
\text { Morgantown, WV } 26501 \\
\text { Phone: } 304-284-0992\end{array}$ & \\
\hline
\end{tabular}

* Disclaimer: Service availability is subject to change, please call each facility for details 


\section{Appendix G}

\section{Evaluation of the Acceptability of the Development and Usefulness of the Protocol}

Please answer the following questions after you have read the Preventing Unintended Pregnancy in Homeless Women in Monongalia County Protocol:

Qualtrics Survey using Likert scale: 1-5 (Strongly Agree > Strongly Disagree) with option for comments and a few short answer questions.

This survey is used to 1) evaluate the acceptability of the development of the protocol and 2) usefulness of the protocol. The survey will take you about 20 minutes to complete. Name and Organization (optional)

\section{Acceptability of the Development of the Protocol}

1. I found the focus group fostered open ended discussion.

2. I felt I had adequate time to share my experiences and ideas with the group.

3. I felt the focus group members accurately reflected community stakeholders for this population (homeless women at risk for pregnancy) in Mon. County.

4. I think the questions asked by the facilitator (Jessica) were relevant to creating this protocol.

5. I think this focus group was an effective method for creating this protocol.

6. The protocol adequately reflects the ideas discussed in this focus group.

7. I enjoyed attending this focus group.

8. Are any essential ideas from the focus group or from your experience missing from the protocol? (free text)

9. What stakeholders were missing from this focus group? (free text) 
10. The length of time to complete this focus group was two hours, was this? Too short, just right, too long

11. This protocol is comprehensive.

\section{Usefulness of the Protocol}

12. I think this protocol is important for our community.

13. I think this protocol will make a difference in preventing unplanned pregnancy in homeless women in Mon. County.

14. I think I will be able to help this population better by using this protocol.

15. I think this protocol could be easily implemented in my organization.

16. I think this protocol will NOT be costly to use or implement in my work.

17. I think implementing this protocol will NOT be burdensome to my work.

18. I think this protocol will strengthen collaborations between you and those who provide services to homeless women within the community.

19. This protocol will make a change in your practice.

20. If yes to above question, how so? (free text)

21. My views of preventing unplanned pregnancy in homeless women have changed by creating this protocol.

22. If yes to above question, how? (free text)

\section{Additional Survey Questions to Evaluate Experience and Desire to Continue Project}

23. I made connections with other community stakeholders by participating in this focus group.

24. Would you be willing to be a part of the task force? If yes, please share your name or send me an email. (free text) 


\section{Appendix H}

Budget Plan

\begin{tabular}{|c|c|c|}
\hline Budget Categories & Personal Funds & $\begin{array}{l}\text { Organizational } \\
\text { Contributions }\end{array}$ \\
\hline AMINISTRATIVE COSTS & $\$ 2,450$ & $\$ 0$ \\
\hline \multicolumn{3}{|c|}{$\begin{array}{l}\text { Administrative Justification: Time for the project lead to interview women and service providers. } \\
\text { Estimation for interview time is } \sim 10 \text { hours. Avg NP salary } \$ 49 \times 10 \text { hours }=\$ 490+\text { outside work } \\
\text { on project ( } 40 \text { hours } \times \$ 49=\$ 1,960 \text { ) }\end{array}$} \\
\hline Marketing & $\$ 0$ & $\$ 0$ \\
\hline \multicolumn{3}{|c|}{ Marketing Justification: Done by word of mouth from service providers at key site for interviews. } \\
\hline $\begin{array}{l}\text { EDUCATIONAL MATERIALS/ } \\
\text { INCENTIVES }\end{array}$ & $\$ 50$ & $\$ 0$ \\
\hline \multicolumn{3}{|c|}{$\begin{array}{l}\text { Educational Materials/Incentives Justification: Development of materials following protocol } \\
\text { creation. Incentives were limited since this study was exempt by IRB. }\end{array}$} \\
\hline $\begin{array}{l}\text { HOSPITALITY (food, room rentals, } \\
\text { etc.) }\end{array}$ & $\$ 20$ & $\$ 30$ \\
\hline \multicolumn{3}{|c|}{$\begin{array}{l}\text { Hospitality Justification: Hygiene kits were given to the women courtesy of the key site for } \\
\text { interviews. Limited hospitality provided for the stakeholders attending the in-person meeting. }\end{array}$} \\
\hline $\begin{array}{l}\text { PROJECT SUPPLIES (office } \\
\text { supplies, postage, printing, etc.) }\end{array}$ & $\$ 30$ & $\$ 20$ \\
\hline \multicolumn{3}{|c|}{$\begin{array}{l}\text { Project Supplies Justification: } \$ 30 \text { of personal funds for thank you notes to participants, printing } \\
\text { of protocol. Printing could also be facilitated by SON. } \\
\text { Protocol could also be e-mailed to service providers for easy editing in the future (free). }\end{array}$} \\
\hline TRAVEL EXPENSES & $\$ 1000$ & $\$ 0$ \\
\hline \multicolumn{3}{|c|}{$\begin{array}{l}\text { Travel Expenses Justification: visiting service providers and women for interviews ( } 1 \text { visit to WV } \\
\text { for focus group) }\end{array}$} \\
\hline OTHER & $\$$ & $\$$ \\
\hline \multicolumn{3}{|l|}{ Other Justification: N/A } \\
\hline TOTALS & $\$ 3550$ & $\$ 50$ \\
\hline
\end{tabular}




\section{Appendix I}

\section{Measurable Project Objectives Evaluation Plan}

Creating a Community-Based Protocol to Prevent Unintended Pregnancy in Homeless Women in Monongalia, County, WV

\begin{tabular}{|c|c|c|c|c|c|c|}
\hline Aim & Outcomes & Objective/Criteria, AEB & $\begin{array}{l}\text { Target } \\
\text { Population }\end{array}$ & $\begin{array}{l}\text { What Data to } \\
\text { Collect }\end{array}$ & $\begin{array}{l}\text { Collection } \\
\text { Methods }\end{array}$ & Data Analysis \\
\hline $\begin{array}{l}\text { Aim 1: Engage } \\
\text { community } \\
\text { stakeholders and } \\
\text { homeless women in } \\
\text { developing a } \\
\text { strategy to reduce } \\
\text { unintended } \\
\text { pregnancy in } \\
\text { homeless women. }\end{array}$ & $\begin{array}{l}\text { A protocol, } \\
\text { based on input } \\
\text { from homeless } \\
\text { women and } \\
\text { stakeholders, } \\
\text { that will guide } \\
\text { intervention for } \\
\text { homeless } \\
\text { women to } \\
\text { prevent } \\
\text { pregnancy }\end{array}$ & $\begin{array}{l}\text { Obtaining input from } \\
\text { women and stakeholders, } \\
\text { create a community-based } \\
\text { protocol to guide } \\
\text { intervening with homeless } \\
\text { women in need of } \\
\text { prevention of unintended } \\
\text { pregnancy, AEB: } \\
\text { 1a: Interviews with homeless } \\
\text { women } \\
\text { 2a: Participation and input } \\
\text { from stakeholders } \\
\text { 3a: A document, not to exceed } \\
5 \text { pages, to guide intervention }\end{array}$ & $\begin{array}{l}\text { Stakeholders: } \\
\text { homeless } \\
\text { women, } \\
\text { homeless } \\
\text { shelters, } \\
\text { health } \\
\text { department, } \\
\text { department } \\
\text { of } \\
\text { corrections, } \\
\text { Health Right, } \\
\text { OB/GYN } \\
\text { providers }\end{array}$ & $\begin{array}{l}\text { Quantitative } \\
\text { data, } \\
\text { including } \\
\text { demographics } \\
\text { and data } \\
\text { describing use } \\
\text { of services. } \\
\text { Qualitative } \\
\text { data } \\
\text { describing } \\
\text { patterns of use } \\
\text { of services } \\
\text { and perceived } \\
\text { needs of } \\
\text { homeless } \\
\text { women }\end{array}$ & $\begin{array}{l}\text { Qualitative } \\
\text { interviews } \\
\text { with } \\
\text { homeless } \\
\text { women and } \\
\text { focus group } \\
\text { with } \\
\text { community } \\
\text { stakeholders }\end{array}$ & $\begin{array}{l}\text { Content } \\
\text { analysis of } \\
\text { interviews } \\
\text { and focus } \\
\text { group data }\end{array}$ \\
\hline
\end{tabular}




\begin{tabular}{|c|c|c|c|c|c|c|}
\hline Aim & Outcomes & Objective/Criteria, AEB & $\begin{array}{l}\text { Target } \\
\text { Population }\end{array}$ & $\begin{array}{l}\text { What Data } \\
\text { to Collect }\end{array}$ & $\begin{array}{l}\text { Collection } \\
\text { Methods }\end{array}$ & $\begin{array}{l}\text { Data } \\
\text { Analysis }\end{array}$ \\
\hline $\begin{array}{l}\text { Aim 2: } \\
\text { Evaluate } \\
\text { community } \\
\text { stakeholders' } \\
\text { views of the } \\
\text { acceptability } \\
\text { of the } \\
\text { process of } \\
\text { creating the } \\
\text { protocol and } \\
\text { the } \\
\text { usefulness of } \\
\text { the protocol }\end{array}$ & $\begin{array}{l}\text { Comprehensive/constructive } \\
\text { evaluation of the protocol } \\
\text { completed by the } \\
\text { stakeholders attending focus } \\
\text { group }\end{array}$ & $\begin{array}{l}\text { Obtaining input from } \\
\text { stakeholders on the protocol, } \\
\text { AEB: } \\
\text { 1b: Acceptability of the process } \\
\text { of development } \\
\text { a. Adequate } \\
\text { representation of } \\
\text { focus group's views } \\
\text { in the protocol } \\
\text { b. Accurate } \\
\text { representation of the } \\
\text { community in the } \\
\text { focus group } \\
\text { c. } \text { Openness/freedom } \\
\text { to share ideas during } \\
\text { the discussion } \\
\text { d. Comprehensive and } \\
\text { concise } \\
\text { e. Time to invest in the } \\
\text { process } \\
\text { 2b: Usefulness of the protocol } \\
\text { f. } \begin{array}{l}\text { Effectively } \\
\text { addresses the needs } \\
\text { of the population }\end{array} \\
\text { g. Relevant changes } \\
\text { are easy to } \\
\text { implement } \\
\text { h. Creates a change in } \\
\text { practice (mentality } \\
\text { and practically) }\end{array}$ & $\begin{array}{l}\text { Community } \\
\text { stakeholders } \\
\text { attending } \\
\text { focus group }\end{array}$ & $\begin{array}{l}\text { Complete } \\
\text { protocol } \\
\text { evaluations } \\
\text { from all } \\
\text { attending } \\
\text { stakeholders }\end{array}$ & $\begin{array}{l}\text { Qualtrics } \\
\text { protocol } \\
\text { evaluation } \\
\text { survey } \\
\text { using } \\
\text { Likert } \\
\text { scale (1-5 } \\
\text { strongly } \\
\text { agree> } \\
\text { strongly } \\
\text { disagree) } \\
\text { with } \\
\text { comments } \\
\text { section }\end{array}$ & $\begin{array}{l}\text { Qualtrics } \\
\text { analysis } \\
\text { of } \\
\text { evaluation } \\
\text { questions } \\
\text { Assess } \\
\text { comment } \\
\text { section for } \\
\text { themes }\end{array}$ \\
\hline
\end{tabular}




\section{Appendix J}

\section{Phone Interviews with Homeless Women in Morgantown}

\begin{tabular}{|c|c|c|}
\hline & Interview Questions & Specific Descriptors in the words of participants \\
\hline & $\begin{array}{l}\text { What are the main } \\
\text { challenges of being a } \\
\text { homeless woman in Mon }\end{array}$ & $\begin{array}{l}\text { "Sundays...nowhere to go, Health Right is closed and nowhere to sit, Bartlett House opens at } \\
\text { 8pm" (resorts to going to her boyfriend's son's friend's home) } \\
\text { "Out in the cold... Not having a job... Struggling with everything..." } \\
\text { "Basic needs are not met...weeks since I showered...I live in an abandoned house; I usually } \\
\text { just wipe down or shower at a friend's" } \\
\text { "Drugs" } \\
\text { "Guys think they can get anything off a woman, so I hang out by myself" } \\
\text { "No car" (men offering a ride) }\end{array}$ \\
\hline & $\begin{array}{l}\text { What do you think it } \\
\text { would like to be homeless } \\
\text { and pregnant in this }\end{array}$ & $\begin{array}{l}\text { "Horrible, all I want to do is sleep but I have to get up to walk my boyfriend's son to the bus at } \\
\text { "S30am" } \\
\text { "Shelter closes at } 745 \text { am and Friendship House opens at 8am" } \\
\text { Currently pregnant and going to doctors' appointments: "friend helps with transportation } \\
\text { otherwise I take the bus or social worker at Health Right sometimes will help..." } \\
\text { "I don't know...I'd be pushing harder to get a place so the baby would have a place" } \\
\text { "I would shoot myself-h*1l, no! I would not want extra medical needs...twice as hard... I } \\
\text { barely get my own needs met" }\end{array}$ \\
\hline
\end{tabular}




\begin{tabular}{|c|c|}
\hline & "I've done that...walking everywhere. Have to be out of the shelter early in the morning" \\
\hline $\begin{array}{l}\text { 3. What do you think is the } \\
\text { best way to prevent } \\
\text { unintended pregnancy? } \\
\text { Do you think other } \\
\text { women who are homeless } \\
\text { would agree? }\end{array}$ & $\begin{array}{l}\text { "Health Right offers birth control. All you have to do is go get it [at the pharmacy] and they can } \\
\text { give it to you at the office." } \\
\text { "Not do anything to get pregnant...Use condoms?" } \\
\text { "Birth control...I think depo is the most logical...it's a shot you get every 1-2 years" } \\
\text { "Don't have sex" } \\
\text { "Hardly have a phone so I don't know what time it is...I would miss pills" } \\
\text { "Condoms only work half the time--break a lot" } \\
\text { "Most of my friends can't have kids anymore because of hysterectomy or menopause" } \\
\text { "Most people play craps... if it didn't happen last time... hope for the best" } \\
\text { "Birth control at Health Right or a doctor at Ruby..." }\end{array}$ \\
\hline $\begin{array}{l}\text { 4. What do you think is the } \\
\text { main reason unintended } \\
\text { pregnancies happen in } \\
\text { homeless women? }\end{array}$ & $\begin{array}{l}\text { "Nobody is paying attention to their cycle..." } \\
\text { "Too high to even care" } \\
\text { "A way out of the homeless environment... } \\
\text { moved to top of HUD list or to West Run apartments..." } \\
\text { "Don't know..." } \\
\text { "No phone...often stolen, can't keep up with the time" } \\
\text { "Timing of pills is difficult to remember..." }\end{array}$ \\
\hline
\end{tabular}




\begin{tabular}{|c|c|}
\hline & $\begin{array}{l}\text { "The first thought on our mind is NOT 'I'm (or not) going to get pregnant'..." } \\
\text { "Hope for the best..." } \\
\text { "Let me get a ..." (sex) } \\
\text { "Live by the seat of your pants..." } \\
\text { "I have friends who have lost kids... they say 'whatever'..." } \\
\text { "Starts with a relationship that includes housing... woman gets pregnant and is back on the } \\
\text { street...man doesn't want to take care of the family; woman ends up back on the street and the } \\
\text { child ends up in foster care..." } \\
\text { "I have six kids", }\end{array}$ \\
\hline $\begin{array}{l}\text { 5. Do you think Mon County } \\
\text { is helpful to women who } \\
\text { are homeless? How? }\end{array}$ & $\begin{array}{l}\text { "Not more than they are to anyone else..." } \\
\text { "Helpful to everybody...jobs, social security... these are necessary to live healthy" } \\
\text { "As much as they can be...Always more that can be done" } \\
\text { "Improvements: more available hours (i.e. Health Right closes at 4pm) ... stuff happens after } \\
\text { closing hours..." } \\
\text { "More services in town so I don't have to go to the hospital..." } \\
\text { Ex: "I went to HR with an abscess and they told me I had to go to the hospital...I don't like } \\
\text { going to the hospital because I have to walk home...the ambulance can take me to the hospital, } \\
\text { but I still have to walk back and I get dope sick on my way back..." } \\
\text { "Transportation...bikes often stolen and traded to dope dealers...not always accessible" } \\
\text { "No... I have been homeless for } 3 \text { years..." }\end{array}$ \\
\hline
\end{tabular}




\begin{tabular}{|c|c|c|}
\hline & & "Get women off the street, women need to be in housing!" \\
\hline & $\begin{array}{l}\text { What about women who are } \\
\text { homeless and pregnant in } \\
\text { Mon County? How? }\end{array}$ & $\begin{array}{l}\text { "Not really, they give you food stamps and medical..." } \\
\text { "Some women think they can't work while pregnant, but I rather work than sit around... (currently } \\
\text { unemployed)" } \\
\text { "Not sure..." } \\
\text { "Depends on the person taking every necessary step they need to... accessing every opportunity and } \\
\text { available resource..." } \\
\text { "Many think if you access the resources, they will lose the kid the day they come out..." } \\
\text { "I have two friends who recently had babies...one died, it was decomposing in her body, the other lost } \\
\text { the kid (to the state)...I was living with them and doing the same stuff (drugs)...They didn't have any } \\
\text { healthcare...had previous kids...doing dope...One had a warrant...the other is too lazy..." } \\
\text { Follow up question: Did you ever talk about birth control? "We never talk about birth control } \\
\text { If I wanted birth control, I would talk to a nurse (mentioned RN at HR)." } \\
\text { "Sober Living" } \\
\text { "Ruby-not helpful with housing" }\end{array}$ \\
\hline & $\begin{array}{l}\text { How do you think this } \\
\text { community could improve in } \\
\text { helping women who are } \\
\text { homeless to prevent } \\
\text { unintended pregnancy? }\end{array}$ & $\begin{array}{l}\text { "More clinics like Health Right" } \\
\text { "less waiting" } \\
\text { "birth control worked for a while, everything was going good and we decided we wanted a baby...I am } \\
\text { due in August" } \\
\text { "More help with housing" } \\
\text { "Churches that feed everyday" } \\
\text { "Kids }<2 \text { only allowed at Friendship House, more safe areas where moms could bring their kids..." } \\
\text { "Medical health is a priority to me... when I had my abscess, I came every day to Health Right to get it } \\
\text { cleaned..." }\end{array}$ \\
\hline
\end{tabular}




\begin{tabular}{|l|l|}
\hline $\begin{array}{l}\text { "Not everyone views their health the same way..." } \\
\text { "Nurse at Health Right is who I talk to or SW at Friendship House" } \\
\text { Follow up Question: Who brought up birth control? "RN at Health Right..." } \\
\text { Follow up question after she said depo was every 1-2 years: How do you know when you need your shot } \\
\text { again? "I usually ask RN at Health Right... I don't have a phone so I can't do the "daily thing" ... I lose } \\
\text { stuff all the time, so I ask RN at Health Right to keep up..." } \\
\text { Follow up: When is your next shot? "I'm not sure... I need to ask RN at Health Right..." } \\
\text { "Place for pregnant women to have housing and complete some kind of guidelines or training to stay } \\
\text { there-hoping it will lead to permanent housing with the baby..." }\end{array}$ \\
\hline
\end{tabular}

